\title{
A Cytological Study of Pollen Development in Lactuca.
}

\author{
BI \\ R. RUGGLES GATES, PH.D., F.L.S., \\ Reader in Botany, University of London (King's College), \\ AND \\ E. M. REES, B.SC., \\ Demonstrator in Botany, King's Coliege.
}

With Plates XVI-XIX.

INTRODUCTION.

I $\mathrm{N}$ the following account we propose to describe the cytological phe1 nomena of meiosis in the pollen development of cultivated lettuce, Lactuca sativa, also the history of the tapetal cells and the later development of the pollen grains. Cultivated lettuce is generally supposed to have been derived from L. Scariola, L., and has been in cultivation for over two thousand years. But as L. Scariola occupies the whole of the Mediterranean region and Eastern Asia, it probably contains a number of microspecies, from one or more of which the cultivated varieties were originally derived. Some of the peculiarities of pollen development suggested a possible effect of this long period of cultivation. We have, therefore, compared the cultivated lettuce with the two wild species L. Scariola, L., and $L$. muralis, Fres., in all points in which an effect of cultivation on L. sativa seemed possible.

The earlier stages of the work were completed, and a preliminary account of the results published by the senior author (Gates, 1920). All the later preparations and the whole of the drawings have been made by the junior author, and all stages of the development have been critically studied by us both. All of the cytological material was obtained from the John Innes Horticultural Institution; Merton, through the kindness of the Director, Dr. W. Bateson, F.R.S., who is making a genetic study of certain cultivated lettuces and wild species of Lactuca.

[Annals of Botany, Vol. XXXV. No. CXXXIX. July, 1921.]

$\mathrm{B} \mathrm{b}$ 
The material originally collected in 19 I 9 came from a sowing of commercial seed of Sutton's 'Dwarf Perfection'. This is essentially a Cos lettuce and habitually throws I to 2 per cent. of 'rogues', the rogue resembling a Cabbage lettuce. The type, however, when carefully selfed, we are informed by Dr. Bateson, breeds true as far as present experience goes, some five hundred offspring all remaining true to type. But the rogues 'throw a profusion of forms, ranging from a small percentage of good Cabbage lettuces, through miscellaneous mongrels, to an occasional plant approaching Cos, but I doubt if a true Cos, or even a true Dwarf Perfection, came in some hundreds of them' (Dr. Bateson in letter). There are difficulties with the view that the rogues are cross-bred, and these preliminary results of Bateson are referred to here as indicating all that is at present known concerning the relationship of the type and the rogue. Cytologically, the type and the rogue are very similar, and no certain differences have been established between them.

The most satisfactory fixing fluid was found to be I per cent. chromoacetic acid solution, and Heidenhain's iron-alum-haematoxylin gave the most sharply defined and satisfactory staining results for most purposes. The sections were cut chiefly Io $\mu$ in thickness. The figures are all of cultivated lettuce, and no distinction is made between the type and the rogue except in the explanation of plates at the end of the paper.

\section{Early History of Pollen Mother-cells and Tapetum.}

In a longitudinal section of the buds of lettuce, a very small number of pollen mother-cells appears in each loculus. Numerous counts in all the species indicate the presence of from fifteen to twenty mother-cells in each loculus, from which usually about sixty pollen grains develop. Moreover, a striking feature of all three species is the loose arrangement of the cells in even the earliest pollen mother-cell stage. The separation of the sells begins in the archesporium. As shown in Figs. I-4, not only are the pollen mother-cells frequently separated from each other even before synapsis, but they usually lie free from the tapetal cells, and the latter are for the most part more or less completely separated from each other. This last condition is so different from the usual condition in flowering plants in which the tapetum forms a compact and continuous layer of cells, that it was at first thought to be possibly a result of long cultivation. But comparison with the two wild species showed this condition to be equally characteristic of them, and so probably of the genus as a whole.

Another peculiar feature which is associated with the loose arrangement of the tapetal cells is the fact that a variety of transitional stages occur between tapetal cells and pollen mother-cells. During the period when the mother-cells are in synapsis and the postsynaptic spireme stages, the tapetal 
cells vary greatly in appearance, as shown in Figs. 2-4. Individual tapetal cells frequently break down even during presynaptic stages (see Fig. I). They are at this time uninucleate. The tapetal cells become binucleate by a mitotic division at about the time of the onset of synizesis in the pollen mother-cells, or even a little earlier. This division may be somewhat delayed (Fig. 2), but the cells are usually all binucleate by the time synizesis is complete. The second mitotic nuclear division, which makes the tapetal cells quadrinucleate, occurs at the end of the period of synizesis or when the pollen mother-cell nuclei are just coming out of synizesis and forming a loose spireme. These nuclear divisions are usually simultaneous throughout a loculus.

Among the numerous types of tapetal cells, many of them remain, at least for some time, in the binucleate condition. Occasionally, crowding of the spindles or failure of one nucleus to divide will result in a trinucleate cell. The variations and later history of these peculiar tapetal cells will be considered below.

\section{SyNizESIS AND SyNAPSIS.}

In this paper the term synizesis is adopted for the tightly contracted phase of the nucleus, following the usage which has become customary in the literature of animal cytology, while the term synapsis is applied to the whole period from the beginning of contraction in the nucleus, through the various stages of spireme formation until the spireme segments into chromosomes.

Synizesis thus represents the height of the synaptic contraction, which takes place in the earlier stages of synapsis. The essential feature of synapsis has always been considered to be the pairing of elements of maternal and paternal origin. The more recent discovery that the maternal and paternal chromosomes frequently show a tendency to be paired in the somatic nuclei of many plants and animals has rendered it very doubtful whether synapsis is ever concerned at all, in organisms in which telosynaptic reduction takes place, in actually bringing about the paired association. This phase of the subject will be considered later.

Fig. 5 represents a presynaptic pollen mother-cell in which the nucleus is occupied by a uniformly distributed reticulum of fine, anastomosing threads. This threadwork is only slightly thickened at the nodes, and there is no trace of prochromosomes in the resting stage. Almost invariably a single large nucleolus is present, but very occasionally two have been observed. The first indication of the onset of synizesis is the appearance of a clear space at one side of the nucleus, accompanied by a thickening of the reticulum threads (Fig. 6). Many mother-cell nuclei have been seen in this condition where other nuclei in the same section show later stages of synizesis, as represented in Figs. 7-II. The cytoplasm of such cells is properly fixed and not unduly contracted. 
It therefore seems clear that the appearance of this hyaline area, which is always at one side of the nucleus and in contact with the nuclear membrane, is the very beginning of synizesis. Sometimes at this stage the nuclear membrane appears to be ruptured as though from internal pressure, leaving a small clear area at the point of rupture extending into the cytoplasm. The cause of this condition is obscure. In Fig. 6 the reticulum appears to have been drawn away from the nuclear membrane. Figs. 7-10 illustrate further advance of this contraction. The reticulum is gradually withdrawn from the nuclear membrane, sometimes uniformly at all points, so that the contracted mass comes to lie in the centre of the nucleus, but more usually to one side, where it still remains in contact with the nuclear membrane.

In the early stages leading to synizesis, represented by Figs. 7-10, while the nuclear reticulum is undergoing varying degrees of contraction, it is at first usually surrounded by an extremelly delicate membrane, probably osmotic in character and much thinner than the nuclear membrane, which enables the contracting threadwork to preserve a more or less perfectly spherical form. Delicate threads may be present, connecting the reticulum with the nuclear membrane (Fig. 9), or no such threads may be visible (Fig. 8). These threads may be secondary in origin. When present, they apparently tend, by their attachment to the nuclear membrane, to give the contracting reticular membrane a wavy outline. Fig. Io represents a slightly different condition which is of more frequent occurrence. Here the delicate membrane surrounding the reticulum has apparently never been complete in itself, being completed by a portion of the nuclear membrane to which the threads of the reticulum remain attached, though obviously drawn out from their original position.

In both these cases, whether the reticulum becomes completely free from the nuclear membrane or remains attached by one portion, the necessary conditions are present for the functioning of an osmotic membrane enclosing the reticulum. Exactly how this membrane arises we do not know. It appears to be a precipitation membrane which is laid down after the contraction of the nuclear reticulum has begun to withdraw the latter from contact with the nuclear membrane, and hence appears where the reticulum comes in contact with the karyolymph. It is possibly first formed in contact with the nuclear membrane, and then gradually withdrawn from that membrane. In L. Scariola it is usually more conspicuous than in lettuce. It is owing to this membrane that the reticulum still retains in most cases its spherical outline, the evenness of which is an indication of the presence of a limiting membrane. This membrane has in fact been clearly observed in a large number of nuclei at this stage, and can be readily made out from Figs. 8 and Io.

The possible manner of functioning of such an osmotic membrane 
is clear. If it is semipermeable, and the clear area of karyolymph surrounding the reticulum contains more strongly osmotic substances, then progressive contraction of the network would take place as water is withdrawn into the clear area between this membrane and the nuclear membrane. The excellent fixation of the cytoplasm in these cells makes it very difficult to suppose that these phenomena result from the treatment.

But it is evident that the presence of an osmotic membrane surrounding the reticulum will not entirely account for the contraction, because numerous stages of contraction have been seen where no such membrane is present. In view of the statement made by Lawson (1911), that the apparent contraction is really due to the sudden growth of the nucleus and is not a true contraction, a series of measurements were made beginning with the resting stage and ending with the postsynaptic spireme. These measurements showed conclusively that, in Lactuca at least, there is a real contraction of the nuclear content. There is at the same time a steady increase in the nuclear volume, and the two phenomena appear to be more or less simultaneous, though the contraction may begin first, and the nuclear expansion usually continues after the reticular contraction is completed. The suggestion of Davis (1910), that contraction is due to shortening and thickening of the threads of the network previous to their transformation into a spireme, also deserves consideration. Comparison of the reticula in Figs. 8-10 with the resting nucleus shows clearly that the threads in the former take up considerably less space, but it has been impossible to find clear evidence that the threads are individually noticeably thicker. A membrane surrounding the contracting reticulum might then function as an osmotic aid to contraction, but that contraction can take place in its absence is shown by such figures as 7 . At times, as in Fig. 7, the transformation of the thread into a spireme occurs prior to the formation of the true synaptic knot.

As the contraction proceeds it is often accompanied in its later stages by a rearrangement of the threads of the reticulum to form a more or less continuous spireme. It is impossible to determine the exact nature of this rearrangement of threads. It appears to be a process quite distinct from the contraction, and in many cases (Fig. 7) the rearrangement is already taking place before the contraction has proceeded very far. In such cases the nuclear membrane is frequently not intact, and there is no evidence of a precipitation membrane. Nuclei in this condition at first suggest artifact, but the cytoplasm is well fixed, and as contraction of the nuclear content takes place in different directions in adjacent cells there is no reason for attributing it to the fixing fluid. The stages represented by Figs. 8-10, compared with Fig. 7 , indicate that the amount of contraction of the reticulum may perhaps be conditioned to some extent by the presence of a precipitation membrane. 
Even though possibly a certain amount of derangement of the nuclear content takes place during fixation, yet it is clear that these nuclei represent a peculiar physiological condition of the nucleus at the onset of synizesis. This is indicated by the manner of their occurrence, for usually the cells of a loculus will all show approximately the same condition, while adjacent loculi in the same section will be in other stages of development. Thus Figs. 8 and 9 are from one loculus, and Figs. 7 and Io from an adjacent one. Typical synizesis, and later postsynaptic spireme stages (Figs. II-I2), may also occur in the same slide or in different flowers of the same section. Since synizesis itself and the later spireme stages are universally recognized as normal developmental stages, the same status must be accorded to the transition stages represented by Figs. 7-10.

All the above stages are exact duplicates of conditions described by one of us in Oenothera rubrinervis (Gates, 1908, see P1. I, Figs. 12-15), and in Oe. gigas (Gates, 1911, see Pl. LXVII, Figs. 2-6). Fraser (1914) has also figured in Vicia Faba (Figs. 2, 3) conditions very similar to our Figs. 6-10. In Oenothera there was evidence of expansion or growth of the nuclear membrane at this time, as well as contraction of the nuclear contents.

Lawson's (1911) view that in synizesis there is 'a great accumulation of sap within the nuclear cavity' which 'causes great osmotic pressure', producing a distension of the nuclear membrane, is quite inadequate to explain the phenomena observed. His results with Smilacina as to the absence of any contraction of the nuclear content at this period have not been confirmed in any other plant, and McAllister (1913) has since figured typical synizesis in this genus. Consideration of all the results show that while there is a certain amount of expansion or growth of the nuclear membrane both in Oenothera, Smilacina, and Lactuca, there is also a notable contraction of the nuclear reticulum at the same time. In Lactuca and also in Oenothera there is clear evidence of a delicate membrane surrounding the reticulum in the early stages of its contraction.

In Lactuca the evidence for contraction of the nuclear reticulum is conclusive, but there is also clear evidence of growth of the nucleus during the later stages of synizesis (Fig. 4). This growth and a number of other size relationships are shown in the table of comparative measurements given below.

Each figure given is the average of twenty-five measurements, or in a few cases ten measurements. The range of variation was small except in the synizesis stage of the cells in L. Scariola marked (*). The number of measurements, while not large, was found to be sufficient for the present purpose. Reading down the vertical columns, there is seen to be a steady growth in the size of the mother-cell from the presynaptic to the postsynizesis stage. The same is true of the nucleus during this period. The 
difference between the synizesis and postsynizesis measurements in $L$. Scariola as regards size of both cells and nuclei is probably not significant, and this would appear to indicate that cell growth ceases earlier in this species than in the lettuce.

TABLE I. Dimensions of Cells and Nuclei in Lactusa.

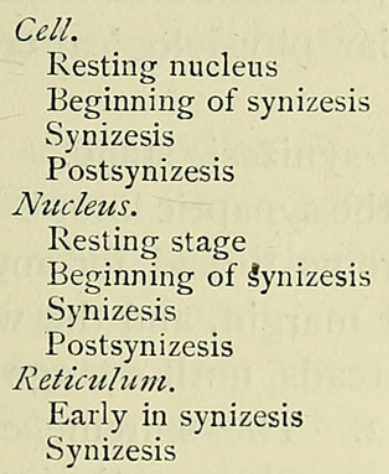

\begin{tabular}{|c|c|}
\hline $\begin{array}{c}\text { Lettuce - Rogue. } \\
\text { Average Diameter. } \\
\text { mm. }\end{array}$ & $\begin{array}{c}\text { L. Scariola. } \\
\text { Average Diameter. } \\
\text { mm. }\end{array}$ \\
\hline 19.7 & $: 7.7$ \\
\hline $20 \cdot 3$ & I $7 \cdot 8$ \\
\hline $2 \mathrm{I} .8$ & $23 \cdot 4^{*}$ \\
\hline 26 & $22 \cdot 5$ \\
\hline $\mathrm{II} \cdot 4$ & IO.I \\
\hline I 2.8 & I $3 \cdot 4$ \\
\hline$I_{4} \cdot 2$ & 14.9 \\
\hline I 5.2 & 14.6 \\
\hline $\begin{array}{l}7 \cdot 7 \\
6 \cdot 5\end{array}$ & $\begin{array}{l}7 \cdot 4 \\
7 \cdot 4\end{array}$ \\
\hline
\end{tabular}

That in synizesis the reticulum undergoes contraction to approximately half the diameter of the nucleus is shown by comparison of the last two lines of the table with the preceding lines. Needless to say, all the nuclear measurements were taken from nuclei which had not been cut, so that the whole of the contracting reticulum or synaptic knot was present. With nuclei of such small size this is easily done when the sections are $10 \mu$ thick.

Hitherto, synizesis has only been reported from spore mother-cells in plants and in the primary spermatocytes and oocytes of animals. This has emphasized the purely morphological or developmental aspects of the process. It evidently represents a unique and critical stage in the life cycle of any sexually reproduced organism, having been observed even in such low organisms as the Myxomycetes (Olive, 1907). But like every other developmental stage, it must be produced by antecedent physiological conditions which bring it about. These conditions usually arise only in spore mother-cells. But a peculiarity of Lactuca, as already pointed out, is the presence of a variety of intergrades between pollen mother-cells and tapetal cells. The presence of such intergrades is believed to account for the occurrence of synaptic phenomena in cells which are essentially tapetal cells.

Fig. 74 shows a binucleate tapetal cell with its nuclei in synizesis. That it is a tapetal cell and not a binucleate microspore mother-cell, such as Fig. I5, is shown by its position. It forms a part of the tapetal lining of the loculus, while the pollen mother-cells are in the postsynaptic spireme stage. The adjacent tapetal cells do not show this condition, except one trinucleate cell (Fig. 82) on the opposite side of the loculus. The central 
nucleus of this cell has probably been formed by the close approach to each other of the inner ends of the two spindles present during the second mitosis, leading to the coalescence of the two inner daughter nuclei into one at the time of their formation. This frequently happens in tapetal cells owing to the crowding of the spindles, so that a number of the tapetal cells are trinucleate after the second mitosis. In Fig. 82 this central fusion nucleus is in a somewhat later synaptic condition than the two end nuclei. The fact that synizesis occurs in these cells cannot, we think, be attributed to the fixation, but must rather be an indication of a peculiar physiological condition of these nuclei.

Fig. I I shows a mother-cell in the typical synizesis stage. Even with the most careful treatment and differentiation, the synaptic knot is invariably so dense that it is impossible to trace the spireme thread for any distance. Soon, however, threads begin to appear at the margin, and the whole mass is seen to be composed of looser and thicker threads, until a stage is reached such as shown in optical section in Fig. 12. The spireme emerges as a thick uniform thread which is apparently more or less continuous throughout its length, though occasionally free ends may be observed. No trace of any parallelism of the threads has been found in these early stages, the thread appearing uniform and unsplit, even when weakly stained. As the spireme spreads out through the nuclear cavity after synizesis, definite loops very soon make their appearance, as seen in Figs. I8-23. At first it is impossible to make an accurate count of these loops. Figs. I8-20 show early stages in the process of looping. The sides of the loops come to be more or less parallel, and it will be seen that the two sides of a loop are also beginning to twist round each other. This latter feature becomes more and more evident in the later stages. As the process of looping continues, it is possible to make a rough count of the number of these loops, and it is found to be approximately nine, i.e. the number corresponding to the gametic number of chromosomes (Figs. 23-29). Finally the loops gradually become detached from each other. There is at this time no definite polarization of the spireme loops. They do not radiate regularly from the centre of the nucleus, nor are they polarized in any other way corresponding to the 'bouquet' stage which occurs in the presence of a centrosome; also no definite second contraction stage has been observed, such as occurs in various other plants. The loops continue to be well distributed through the nucleus.

While the spireme, now a pachynema, is for the most part uniform in appearance during this period, it is by no means universally so. As the figures show, thinner threads are occasionally found connecting thicker portions of uniform thickness. Also some portions may have a beaded appearance owing to the alternation of lighter and darker areas along the threads. But none of these appearances when critically studied permit of 
the interpretation that they have anything to do with a possible conjugation of parallel threads. While it is difficult to affirm from direct observation that no such parasynaptic conjugation of parallel threads takes place during synizesis, yet we have found no evidence whatever which would bear such an interpretation, and we believe the nature of the later stages excludes the possibility of its occurrence. The thread might of course become double at this time through a split, as has been described in various forms, but in Lactuca we have found no indication of a split during this period. The thread remains persistently single as it becomes progressively shorter and thicker.

The segmentation of the spireme into separate loops is a progressive affair, different loops becoming gradually detached. Figs. $23^{-2} 5$ show a stage in which a few loops are free while the others are still connected in a continuous spireme. At this time the characteristic twisted appearance of the loops becomes yet more marked. The detached loop in the lower part of Fig. 23 shows this very clearly. That certain chromosome pairs frequently become detached from the spireme and undergo precocious condensation was shown in the case of Oenothera (Gates, 1908, P1. II, Figs. 20-24), but in that genus the chromosomes are so short and thick that there is never any twisting of the members of a pair about each other during the condensation period. Twisting of the chromosomes about each other, with subsequent breaking at the nodes, is therefore apparently excluded. Its absence in Oenothera may perhaps be genetically significant, since it is known that in that genus the characters in crosses usually have a strong tendency to remain together in groups instead of showing either free assortment or 'crossing over'.

Fig. 30 represents a later stage in lettuce, where all the loops have become free and the twisting has reached its climax. The loops clearly correspond in number to the $x$ number of chromosomes, and one is consequently led to the conclusion that each loop represents a pair of homologous chromosomes. The later fate of the loops, which will be described below, completely confirms this view. The only satisfactory interpretation of such an arrangement would appear to be that the spireme is made up of the full somatic number of chromosomes, which are arranged end to end in pairs, the members of which are alternately of maternal and paternal origin. The two members of each pair then bend round and form a loop, so that the parental chromosomes of each pair come eventually to lie side by side but still connected at one end. This is very similar to the course of events in Oenothera (Gates, 1908, P1. II, Figs. 20-26).

The sides of the loops in lettuce then twist around each other. Usually this results in two or three or more turns (Fig. 30), but sometimes the overlapping is only at one point giving a figure 8 (Fig. $3^{\mathrm{I}}$ ). Such figures of course are familiar enough in the cytological literature, having been 
observed in various plants and animals for many years. Their significance as a possible basis for genetic crossing over will be discussed later, and important differences from the chiasmatypy described by Janssens (1909) will be pointed out. Actual proof that this twisting of the homologous chromosomes about each other is followed in any case by an exchange of segments is extremely difficult to get. Inspection of the figures shows that the wrapping of the chromosomes about each other is much more intimate in some cases than others. Quite probably in many cases no exchange of segments follows, but such cases as Figs. 33 and 49 appear to furnish definite evidence in favour of the occurrence of an interchange of loops.

During this period the nuclear membrane is often extremely thin or quite invisible (Figs. 18-23). That the chromosome pairs differ constantly in length in these early stages of their formation, as in the later stages, is clearly shown by such figures as 23 and 28 . This differentiation in length makes it possible to show that the pairing is between homologous chromosomes of similar length, and therefore of maternal and paternal origin respectively.

\section{DIAKINESIS.}

The chromosome pairs, lying almost invariably side by side, and usually more or less twisted about each other, undergo progressive condensation to form the definitive chromosomes. During the later stages of this condensation the chromosomes become very compact, and finally (Figs. 37-48) appear as straight or curved rods of different lengths, usually showing no indication of their bivalent nature, except in some cases by a fork at one end. It is possible that the swelling produced by the fixing fluid may obliterate the line of separation between the two halves of a bivalent chromosome more completely than in the living condition, but in any case the relationship between the two halves is exceedingly close at this time. Clear indications of the twisted condition are often observed until the condensation is almost complete (Figs. 33-36). But the only trace of the double nature of the definitive bivalent chromosomes (Figs. 37-48) is a faint longitudinal split or a fork at one end.

The nine bivalent chromosomes form a graded series which can be arranged in a general way in three groups, three of maximum length (four or five times as long as broad), three of intermediate length (about two or three times as long as broad), and three very short and almost cubical.

Frequently one of the first three is longer than the other two, and the remainder form a series which can only roughly be divided into groups. The curved shape of the chromosomes also frequently renders impossible the determination of their exact length. Hence the variations 
in relative length from one nucleus to another, as shown by the rows of chromosomes in Figs. $37 a$ to $55 a$, are probably not so great as they appear.

It is also clear that, as would be expected, it is the longest pairs which invariably show the most marked twisting in the early stages. Examination of the later stages of diakinesis frequently shows the longest or intermediate pairs with a straight longitudinal split. Two possible explanations of this are admissible. Either the loops which were twisted must untwist again, or the pairs must split apart with 'crossing over' of certain segments. While we have no demonstrable evidence that such a rearrangement of segments rather than untwisting occurs, yet figures such as 33 , and particularly Figs. $34-36$, show that the condition of torsion persists even after the condensation of the chromosomes has progressed far. This gives reason to believe that the subsequent longitudinal split of the bivalent chromosomes will take place across the twists. Moreover, a twist which always untwisted again along the original lines would appear to have no raison d'etre, whatever are the physical or physiological processes which bring about the torsion.

Occasionally ten chromosomes instead of nine have been counted in diakinesis. This has occurred a number of times in the large number of nuclei at this stage whose chromosomes were counted. The explanation, as indicated by Figs. 37 and 40 , is evidently that the two halves of a bivalent chromosome have become separated. In Fig. 40 the two halves of one bivalent are lying parallel and almost separated from each other. The fact that the two bodies marked $a$ in Fig. 37 are narrower than the other chromosomes, and are of equal length, makes it clear that they represent the two halves of a bivalent chromosome. Other cases of precocious splitting are indicated in Figs. 35, 39, 42, and 47, in which several of the bivalents are shaped like the V's or X's which are so usual at this stage in many plants. Their relative infrequence here, as well as other facts, indicates that in Lactuca the members of the chromosome bivalents are held together exceptionally closely. This is in strong contrast with Oenothera, where the attraction which leads to pairing of the chromosomes is exceptionally weak and is a source of irregularities in the distribution of the meiotic chromosomes.

Another irregularity occasionally met with is the presence of only eight pairs (Figs. 46-48). Figs. 45 and 46 indicate how this condition has probably arisen. In Fig. 45 two pairs of bivalents are united by strands of deeply staining material, while Fig. 46 shows seven bivalents of normal length and one extremely long one, formed probably by the union of two long bivalents end to end.

If this structure is composed of two bivalents united end to end it could scarcely have been formed by failure of the spireme to segment 
between them, because that would mean that the body is composed of four consecutive segments which remained attached and in which the end segments must have then folded back on the others. This procedure is unlikely, and it seems more probable that the end to end coalescence took place after the chromosomes of two loops had come to lie side by side.

In certain other cases (see Fig. 48) where only eight bivalent chromosomes were present in diakinesis, probably two of the shorter bivalents had fused end to end, but this could not be determined with certainty because two short chromosomes arranged end to end would be indistinguishable from a single bivalent of intermediate length. These fusions will be compared later with others observed on the heterotypic spindle. We have no positive evidence whether the fusions at this stage are temporary or would persist and affect the later chromatin distribution, but probably the latter would be the case.

\section{Heterotypic Mitosis.}

Between the stage of diakinesis and the arrangement of the chromosomes on the heterotypic spindle, the chromosomes become much more condensed. In the heterotypic metaphase they are condensed to such a degree that there remains comparatively little observable difference in length between them, and many of them appear globular or but slightly elongated. The differences in length during diakinesis are not, however, merely a result of different rates of condensation, for the longer chromosomes undoubtedly contain much more chromatin than the shorter. That the differences in length of the chromosomes are constant features is also shown by the somatic mitoses, in which the same graded series of lengths appear (Figs. 63 and 64).

A striking feature of the heterotypic metaphase is the frequent coalescence (more or less complete) of two or four of the chromosome bivalents, so that only eight or seven bodies appear on the heterotypic spindle. Probably over 50 per cent. show fewer than nine bivalents, seven or eight bodies being the most common number, but sometimes (Fig. 57) no more than five bodies are present. This is in cells in which the figure has not been cut, and must be due to a further coalescence of chromosomes. Such cases were the first to be observed, and it was only later that the cause of this apparent diminution in chromosome number was discovered, through the observation of cases in which the nine bivalents were clearly distinct, and also stages in their fusion. Fig. 50 shows an equatorial view with only seven bodies, and Figs. 53 and 54 side views with eight. In Fig. 50 the two bodies $(a)$ formed by the end to end fusion of two bivalents can be determined. But in Fig. 54 particularly the coalescence is so complete that there is not the slightest indication as to how it has taken 
place. In Fig. 51. is shown a late prophase in which the chromosomes are just being drawn into the equatorial plate. Nine bivalents are present, but two of them are coalesced end to end. There are therefore eight bodies to be seen. Fig. $5^{6}$ also shows eight, the end to end attachment of two being clear. Cells in the intermediate condition with eight 'chromosomes' appear to be quite as frequent as those with seven.

Bands of darkly staining material frequently occur on the spindle, and are seen connecting some of the chromosomes in Figs. 5I and 54. In Figs. 55 and 56 the whole of the spindle is embedded in a mass of denser and more deeply staining cytoplasm. This feature was found to be typical of the wild L.muralis, but these two cells were the only ones found to exhibit the condition in the lettuce rogue and it has not been seen in the type. Fig. 55 represents an equatorial view of the metaphase spindle in which the nine chromosome bivalents are clearly separate.

Figs. 52,53,54,57 show clearly the point of attachment of the spindle fibres, which appears to be terminal in every case. In the last figure the separation of the chromosomes has already begun. All indication of their bivalent nature has at this time completely disappeared. The line of demarcation between the two halves is usually obliterated during diakinesis. This may be partly attributed to the swelling action of the fixing fluid, but even apart from this the two halves of a bivalent must come into very close relationship, especially during the heterotypic metaphase. Again, the coalescence of bivalents at this time cannot be attributed to the fixation, for it occurs in cells where the chromosomes are otherwise loosely grouped. It represents rather a marked tendency to coalescence in which certain of the bivalents appear to be concerned. It is not a mere clumping of the whole chromosome group. The chromosomes are not sufficiently distinguishable at this period to make certain whether two particular pairs of bivalents only are concerned, but the observations lead us to consider that the shorter bivalents are usually concerned, though figures such as $5^{\mathrm{I}}$ and $5^{6}$ indicate that bivalents of intermediate or maximum length may be involved.

Figures such as $5^{\mathrm{I}}$ and $5^{6}$ make it certain that the coalescence is an end to end one, at least in the cases which can be clearly determined. We have seen relatively few heterotypic telophases in which the chromosomes could be counted exactly, but these all showed nine chromosomes, indicating that the coalescence is a temporary one on the heterotypic spindle.

These coalescences on the heterotypic spindle are much more numerous than during diakinesis, and frequently two occur in the same cell. From this it follows that while the fusions during diakinesis probably persist into the heterotypic mitosis, fresh coalescences also arise during that division. The possible genetic significance of these phenomena will be considered later.

Fig. 57, which represents an early anaphase, shows the bivalent 
chromosomes just beginning to separate. The manner of separation of the halves of a bivalent chromosome is shown exceptionally clearly in Fig. $5^{8}$. The spindle is uncut and clearly only seven bodies are present-so that this represents a typical case in which two pairs of bivalents have coalesced. Figs. 52 and 54 have already shown that the point of spindle fibre attachment is at one end of the bivalent chromosomes. Obviously, fibres from opposite ends of the spindle must become attached close together to each half of a bivalent, and at the same end of the chromosome. The appearance (see Fig. 57) is as if the contraction of these fibres pulled the two longitudinal halves gradually apart. Two globular pairs of chromosomes are already completely separated, a short and a longer pair still remain attached by a thread at one end, while in the centre, and less clearly at the left side, of the group, two of the longest pairs are being drawn apart. Focusing on the centre pair shows particularly clearly that its central thicker portion consists of the ends (in vertical orientation) which have not yet separated. Thus five of the pairs have already separated, while the other two may each represent two bivalents fused end to end, which would possibly account for their lagging.

Fig. 59 is from a section of a later anaphase in which fifteen or sixteen chromosomes are present. Fig. 60 represents an early telophase in which the full gametic number (9) is seen in each of the daughter nuclei. Several of these chromosomes at least have already undergone the longitudinal split for the homotypic mitosis and appear as X's and V's. The remains of the spindle are still visible, and the nuclear membranes appear incomplete on the side next the spindle. Some of the chromosomes are already beginning to anastomose. In Fig. $6 \mathrm{I}$ this process is much further advanced and a cell plate is being laid down, while Fig. 62 represents the interkinesis stages. with a loose and heavy threadwork formed in the nuclei. Abnormalities are sometimes found at this time, in which some of the chromosomes pass irregularly towards the poles and frequently give rise to extra nuclei (Fig. 65).

\section{Homotypic Mitosis.}

We have observed relatively few stages of the homotypic division, which as usual is passed through quickly. In the metaphase, polar view, nine univalent chromosomes were counted in some cases. But one spindle in side view showed only six chromosomes, connected by darkly. staining material. It appears that here also coalescence of chromosomes has occurred similar to those of the heterotypic bivalents. But in the absence of more abundant material and with the possibility of the treatment having affected the preparation, we refrain from further interpretation. The stages observed show that in the homotypic mitosis the univalent chromosomes undergo a longitudinal split and separation in the usual way. 


\section{Formation of Pollen Tetrads and Pollen Grains.}

When the reduction divisions are completed, the first evidence of further development in the pollen mother-cell is the beginning of constriction of the cytoplasm at four points placed at equal intervals on its periphery and within the mother-cell wall (Fig. 66). The interval between the cytoplasm and the cell-wall appears to be filled with pale-staining material whose nature has not been investigated. The constrictions of the cytoplasm become progressively deeper until they meet in the centre (Fig. 67) and finally cut up the cytoplasm into four separate masses, the microspores (Fig. 68). As the figures show, this process of constriction of the cytoplasm may take place in the absence of spindle fibres, or it may cut across them before they have disappeared, but in no case were cell plates observed to be laid down on the spindles, the whole process taking place independently of such a structure. Fig. 69 shows a somewhat abnormal tetrad as regards the shape of the mother-cell, and also the way the cytoplasm has been divided up. The mother-cell wall has disappeared and one of the walls has failed to appear, making a central cell with two pollen nuclei. Fusion of these nuclei would give a diploid pollen cell.

It has usually been regarded as an important distinction between the cells of higher plants and animals that whereas in the latter the cytoplasm is segmented after nuclear division by furrowing or cleavage, in plants the new cell-wall is laid down on the spindle. Since Strasburger described the latter method of cell-wall formation in various plants and different tissues, it has usually been assumed to be universal in higher plants. Like so many other distinctions drawn between plants and animals, this is now found to be a general but by no means universal difference. Farr (1916), who refers to the early literature, has described in detail the division of pollen mothercells in Nicotiana by furrowing, exactly as observed in Lactuca. He has observed the process both in living and fixed material, and has also described it (1918) in Magnolia pollen mother-cells. The same method of furrowing has recently been described by Wanda K. Farr (1920) in Cobaea scandens. There is no doubt that it will be found to occur in a large variety of plants, though by no means to the exclusion of the older method, which occurs, for example, in Oenothera (Gates, 1907) and has recently been described in detail (Yamaha, 1920) in Psilotum. Farr (1916) attempts a physical explanation of the furrowing as a result of the accumulation of electrical charges on surfaces and membranes, and the resulting attractions and repulsions which develop.

The young pollen grains within the mother-cell wall begin at once to alter their shape, each one becoming approximately heptagonal in cross section. This is done while the young pollen grain is surrounded only by a plasmatic membrane, and the change in shape can only be a result of the 
cell's own internal activity. It is well known that each genus of higher plants often has its own characteristic form of pollen grain, and it is perfectly certain that the steps towards the assumption of that form which are taken while still within the mother-cell wall must be determined internally by heredity. Whether the later sculpturing of the pollen grain wall is also internally determined, or externally, by apposition of material from the remains of the tapetum, is uncertain. In how far the latter process may take place in the later stages of pollen development has never, we believe, been satisfactorily investigated. But it is clear that the early changes of shape which take place in the young grains within the mothercell are internally determined in all cases. This was shown, for example, in Oenothera (see Gates, 1911, Pl. LXIX, Fig. 47, 48), in which the young pollen grains separate from the centre of the mother-cell, and form within its periphery four discoid cells circular in surface view before the mothercell wall breaks down. Later the characteristic lobes grow out from three equidistant points in the circular edge of the flattened discoid cells. These are also no doubt internally determined, as is proven, for example, by the fact that while the pollen grains of diploid species have three lobes, those of tetraploid species have four or sometimes more.

By the time the young pollen grains in Lactuca have assumed their roughly heptagonal shape, a thin cell membrane has already been secreted around each by the plasmatic membrane of the cytoplasm (Fig. 68). This wall rapidly thickens and develops symmetrical outgrowths (Figs. 70-7I) until it reaches the mature stage shown by the grains in Fig. 72. There is a median frill, pinked at the edges, with usually seven, sometimes five, denser radial bands, which are optical sections of other 'frills' running meridionally. In addition, areas of the cell-wall become greatly thickened to form an approximately circular outline. Whether this complicated and nearly symmetrical system of thickenings is laid down by apposition from the tapetal plasmodium we have not determined, but the irregular margin of the outer thickening suggests that this may be the case. Nevertheless, the general arrangement of the thickenings must clearly be controlled from within the cell, and probably the same is true of the circular thickening.

\section{IRREGULARITIES.}

Under the heading of irregularities are included (I) an account of pollen mother-cells which are binucleate before, during, or after synapsis, and (2) the occurrence of cytomyxis.

\section{A. Binucleate Pollen Mother-cells.}

An interesting feature of the pollen development is the occasional occurrence of binucleate mother-cells. Several such cells are represented in Figs. 14-17. In each of them the two nuclei are in exactly the same 
stage of development, and measurements indicate that they are somewhat smaller than the nuclei of uninucleate cells in the corresponding stages of development. The cells, however, are of normal size or only slightly larger. The earliest stage at which binucleate mother-cells were found (and several were seen in this stage) is the presynaptic condition (Fig. I4). They were not traced farther back into the archesporium stage, and the manner of their origin is uncertain. Fig. I 5 represents a mother-cell with its two nuclei in synizesis, while Figs. I 6 and 17 represent postsynaptic and spireme stages. The latter represents the latest stage in which binucleate mother-cells were found. Theoretically, if such a mother-cell completed the meiotic divisions it should give rise to eight pollen grains, but there is no evidence that this happens. It is possible that such cells break down before the heterotype mitosis. If the meiotic processes were carried through, it is conceivable that pollen grains with two nuclei or a diploid nucleus or some other aberrant condition might result. Possibly some of the aberrant pollen tetrads already mentioned originated from binucleate mother-cells.

Regarding the origin of the binucleate condition in presynaptic cells, we have no absolutely conclusive evidence, but the indications are that it arises through the break-down or incomplete formation of a cell membrane between the two cells.

In the recent literature, a number of cases of binucleate cells in somatic tissue have been described. Their occurrence is so frequent as to indicate that co-ordination between nuclear division and cell-wall formation is by no means universal in growing tissues. The literature of the subject is summarized by Beer and Arber (1920), who have also contributed (1915) many of the recent results. Cells with two or sometimes more nuclei have been observed, particularly in the pith and cortex of the growing region of stems in a variety of plants, such as Asparagus (where such cells appear to be particularly frequent), Evemurus, Helianthus, Monstera, Hemerocallis, Elodea, Stratiotes, \&c. They found binucleate cells in the growing region of the stem in 177 species belonging to the Pteridophytes, Gymnosperms, and Angiosperms. Polynucleate cells were also found in roots and in the mesophyll of leaves. The binucleate or multinucleate condition was found to arise invariably through mitotic rather than amitotic division. The authors (Beer and Arber, 1919; Arber, 1920) have also shown the manner of origin of the binucleate condition. A cell-wall is not laid down in connexion with the cell-plate of the spindle, but the spindle fibres and associated cytoplasm become transformed into an enlarging hollow sphere which expands until it encloses the daughter nuclei and has been called a phragmosphere. The two nuclei so formed in the same cell may differ somewhat in their later behaviour. One may divide without the other, and this division may be followed by cell-wall formation. In other cases C c 
there are indications that the uninucleate condition may be restored by the degeneration of one of the nuclei.

This binucleate condition in meristematic plant cells is of too frequent occurrence to regard it longer as a mere abnormality. Its chief significance appears to be an indication of an incomplete co-ordination between nuclear division and cell-wall formation. Possibly some unfavourable condition, such as a lowering of temperature at the moment of cell-plate formation, might lead to the development of a binucleate phragmosphere. It appears that the condition is a more or less temporary one, with subsequent restoration of a uninucleate condition in older parts by the stem. There is no indication of a phragmosphere in any of the binucleate mother-cells of lettuce, and, as indicated above, we believe this condition to have originated probably in another way, through the break-down of an incompletely formed ceil membrane.

Related phenomena of failure in wall formation after the tetrad divisions have been described in the pollen development of various forms. In Oenothera gigas (Gates, 1911, P1. LXX, Fig. 85), in certain anthers of the flower, the pollen mother-cells failed to round off or free themselves from each other and the tapetum. Such cells not infrequently become quadrinucleate owing to the failure of walls to appear after the reduction divisions, the four nuclei moving together into the centre of the mother-cell. But since these cells are not set free they cannot be functional. Holmgren $(1919$, p. I 3$)$ has described quadrinucleate pollen grains arising in a similar way in Evigeron eriocephahus and E. malaschkensis (Fig. 26, p. I4). He finds them only in certain anthers in the flowers which are transitional between hermaphrodite disc-florets and female ray-florets, but believes they might be functional although they develop a thick wall. A fusion of nuclei in such cells might conceivably give rise to pollen grains which were functionally diploid or even tetraploid.

\section{B. Cytomyxis.}

The condition known as cytomyxis was found to be of relatively frequent occurrence in pollen mother-cells of all species of Lactuca under observation (Fig. I3). It is found to occur frequently during synizesis in otherwise perfectly normal mother-cells where the nucleus of one was so eccentric in position as to come in contact with the cell-wall of an adjoining mother-cell. It was not found to occur necessarily in all cells of one loculus, nor in the same direction, but merely haphazard according to the position of the nucleus with relation to an adjacent mother-cell.

This condition was found to be even more marked in loculi which showed traces of abnormality, for example those in which all or most of the nuclei appeared hyperchromatic. In extreme cases there was complete transference of the chromatin material from one cell into the cytoplasm of an 
adjacent one. Cytomyxis was also observed to take place during the spireme stages, but not so frequently as in synizesis, probably because the mother-cells are more separated at later stages. One case of such transfer of nuclear material was seen at the telophase of the heterotypic division, where it is evidently to be regarded as an abnormality. It seems probable that the phenomenon is not peculiar to any one stage of pollen development, but is merely dependent on the nucleus becoming eccentric and taking up a position where there happens to be an opening at the point of contact with an adjacent cell-wall. That it is in some way connected with a pathological condition of the loculus seems to be indicated by the fact that the phenomenon is of much more frequent occurrence in loculi which are in other ways abnormal than in otherwise perfectly normal ones.

This process, by which a portion of the chromatin from one pollen mother-cell nucleus passes through an opening in the cell-wall into the cytoplasm of an adjacent mother-cell, was first observed by Koernicke (1902) in Crocus. The same process was found by Digby in Galtonia (1909), Primula (1912), and Crepis (1914). Gates (1911) described the process in Oenothera and called it cytomyxis. Nakao (1911) has seen it in rye. Gregory (1905) observed it in a race of Lathyrus odoratus which had sterile anthers, but mistook it for an abnormal division of the pollen mother-cells by constriction. Rosenberg observed it in Crepis (1909 a) and also in Drosera longifolia (1909 b, Fig. II, p. 22). Fraser (1914) found it in Vicia Faba. West and Lechmere (1915) described it as occurring on a large scale in Lilium candidum, although none of the appearances of pollen sterility were found. In this case it must either be normal or induced by the treatment. Sakamura (1916 and 1920) figures it in Vicia Faba, and found it much more frequent in anthers which had undergone chloralization than in those which had not.

The most frequent opinion expressed is that the process is an abnormal one, either pathological or induced by the fixation or treatment, and that it will be followed by break-down of the cells in which it occurs. There are, however, difficulties with this view, and in some cases it is followed by return of the nucleus to a central position and absorption of the extruded chromatin in the cytoplasm of the invaded cell.

\section{DEVELOPMENT OF THE TAPETUM.}

Some features of the early tapetal cells have already been mentioned (pp. 366, 37I). The tapetum is a well-defined layer even at the very early archesporial stages, and is remarkable even then for the elongation of the cells in the direction of the long axis of the anther, that is, at right angles to the usual direction of elongation. The two mitotic divisions of the nuclei in the tapetal cells are usually completed about the end of the synaptic period in the pollen mother-cells. But many of the 
tapetal cells remain in the binucleate condition. This is particularly true of cells near the end of a loculus, but one not infrequently finds the tapetal cells quadrinucleate on one side of a loculus and binucleate on the other (Fig. 4). Binucleate cells are nearly always shorter and broader than the quadrinucleate, and in the latter the nuclei are usually, though not invariably, in a single row. As Figs. I-4 and 7.3-80 show, there is a great variety of sizes and shapes of cells. Figs. 79 and 85 show two extremes. The long narrow cells are usually towards the centre of the loculus. In these binucleate cells particularly the appearance of the nuclei is extraordinarily like that of some of the synaptic stages in the pollen mother-cell nuclei. Figs. 75-8I show the various appearances of the tapetal cells at about the time of diakinesis. It will be seen that the cells are binucleate or quadrinucleate, with different arrangements of the nuclei and various appearances of the nuclear content. The latter may be in the form of a coarse reticulum with karyosomes at the nodes (Fig. 75), or a finer network with sharply marked chromatin bodies which appear to be more independent of the network (Figs. 77,78 ). These bodies are not chromosomes; they are usually rather angular in shape, and are variable in size and number, though often about twelve or thirteen are present. Sometimes they have the appearance of being longitudinally split, and they give the nuclei a hyperchromatic appearance. Winge (1917) has observed and figured (Figs. 5 and 6, p. I50) chromatic bodies having a very similar appearance in the cytoplasm of the young spores of Entorrhiza Raunkiaeriana, a member of the Plasmodiophoraceae, at a time when the nucleus is small, amoeboid in shape, and non-chromatic.

Another type of tapetal cell exists in Lactuca (Fig. 79), small in size, with small nuclei, having a fine network and only one to four large angular chromatin bodies.

It is difficult to say what proportion of the tapetal cells remain binucleate, but probably it is a considerable number. At a later stage of development the nuclei of the tapetal cells frequently fuse with one another, sometimes forming one large nucleus. Or some of the nuclei may break down (Figs. 8I, 85). Finally, at the stage of pollen tetrads the nuclear membranes become very faint (Figs. 83, 86) and disappear, the nuclei more or less completely disintegrating and forming irregular or globular fragments in the cytoplasm. At the same time or a little later the cell-walls, which have become very thin, disappear, and the cytoplasm, containing nuclei in various stages of disintegration, flows in amongst the pollen grains and forms a tapetal plasmodium (Figs. 72, 84).

A tapetal plasmodium was formerly supposed to be characteristic of sporogenesis in Pteridophytes, but not of the Angiosperms. Juel (1915), from a comparative study of the later stages of tapetal development in Angiosperms, finds two extreme types, (I) in which the cells form a true 
plasmodium with active nuclei, $(2)$ in which the tapetal cells are emptied of their contents without the breaking down of the cell-walls. Between these extremes every type of intergrade occurs. A plasmodium was found in Anthurium, Lavatera, Cobaea, Lonicera, Valeriana, and Knautia. In Galium the tapetal cells form pseudopodium-like incursions between pollen mother-cells. The other type, in which the cell-walls remain intact and the cells are finally resorbed, occurs in Hyacinthus, Galtonia, Iris, Tilia, Ulmus, Gaura, Sambucus, Cucurbita, \&c. In Arabis and Limum the condition described closely approaches that found in Lactuca. The tapetal cell-walls disappear very late, producing in the former a plasmodium with disorganized nuclei and in the latter a plasmodium-like disorganized mass. Tischler (1915) finds that in the Commelinaceae the walls of the tapetal cells are lost during synapsis. The plasmodium then wanders in among the pollen mother-cells, its nuclei undergoing changes in form and structure. It is finally resorbed, so that only a trace remains in the ripe anthers. In Commelina coelestis Tischler figures the plasmodium in direct and intimate connexion with the tips of the thickenings on the sculptured walls of the pollen grains.

Pickett (1916) has described in Arisaema how the tapetal cell-walls disappear, allowing the periplasm to spread through the sporangial cavity. He says: "The tapetal nuclei for a considerable period show peculiarities of structure, and take an amoeboid form suggestive of active migration among the developing pollen spores.' While the type of tapetal history is generally the same throughout a large group, there are exceptions in which the tapetum of related families may show quite different behaviour.

\section{DiscusSION.}

\section{The Method of Synapsis.}

From the preceding account it is clear that the method of chromosome reduction in Lactuca is telosynaptic, and essentially in accord with the scheme of Farmer and Moore (1905). There is no indication of a pairing of threads previous to or after synizesis, but the delicate univalent leptonema of synizesis gradually condenses into a relatively short and thick pachynema, which arranges itself into as many loops as the gametic number of chromosomes. Clearly the pachynema is a single thick filament composed of the somatic chromosomes arranged tandem; the homologous paternal and maternal chromosomes alternating. The two arms of each loop of the pachynema constitute a pair of homologous chromosomes lying side by side, and owing to torsion these arms or sides of the loop frequently become wrapped around each other. The looped condition apparently corresponds in time with the second contraction phase of other forms. It differs from the bouquet stage (which apparently occurs in the presence of a centrosome) in 
that the loops are radial or irregular in position instead of being polarized, and when the bouquet stage is accompanied by parasynapsis it of course differs also in the constitution of the individual loops.

The complete loops separate from each other at the base in the segmentation of the spireme. Each bivalent chromosome is thus constituted from the two arms of a loop. This structure condenses greatly, and it appears that in some cases at least the torsion remains. If this account of the formation of the bivalents is true, and we can see no escape from it, then synizesis has no part in bringing about the pairing, and its significance as a unique physiological condition of the nucleus remains entirely obscure.

In the later stages of diakinesis the nine bivalents appear chiefly as rods of different lengths, with sometimes a straight line of fission between their two halves. In many cases even at this time the two halves are so closely associated that no line of separation between them can be observed. On the heterotypic spindle these bivalents become still further condensed, but Fig. $5^{8}$ (Pl. XVIII) clearly shows how in the heterotypic mitosis the longitudinal halves of the bivalents are gradually pulled apart, the separation beginning at one end and proceeding to the other. Whether this line of separation is the same as the line of approximation of the two arms of a postsynaptic loop forming respectively the paternal and maternal members of a bivalent chromosome, depends upon whether the twisting is undone again before the final condensation of the bivalents takes place. In any case this mitosis is essentially a reductional one, although if the separation is across the line of the twists it would only be reductional as regards the individual segments and not as regards whole chromosomes.

This method of reduction differs from that in Oenothera (Gates, 1908) only in that in the latter the pachynema segments directly into a chain of chromosomes which are so short and stout that the members of each pair simply come to lie side by side after the chain segments into pairs connected at one end, since there is no opportunity for them to twist around each other. In Galtonia (Digby, 1910) and Primula (Digby, 1912) the course of events appears to be still more closely similar to that in Lactuca. We therefore regard the telosynaptic course of events as clearly established for a number of plants, but we see no necessity for regarding it as universal for the whole Plant Kingdom. Some years ago it was suggested (Gates, 1910) that both the telosynaptic and the parasynaptic methods of synapsis may occur, the latter perhaps more largely in forms with long thready chromosomes and the former in forms with short and stout chromosomes. Ten years ago the senior author had the opportunity of examining critically the beautiful preparations of Janssens (1905) of Batrachoseps, and was convinced, as Wilson (1912) and others have been since, that an approximation of filaments or univalent spiremes, accompanied by their polarized arrangement, takes place in this form. Janssens's figures, 
such as 15 and 36 , are particularly convincing, and the original preparations still more so, as showing that the lateral pairing of threads is a progressive process beginning at one end of the threads at one side of the nucleus, and proceeding towards the other end, the double threads so formed becoming at the same time polarized in their arrangement. When this process is partly completed, the filaments may be seen to be lying side by side in the paired portion, but diverging widely in the unpaired portion of their length. This would scarcely be the case if the process were simply one of the approximation of the two halves of a single chromosome.

Agar's (1911) figures of the lepto-zygotene and the zygo-pachytene stages in the spermatogenesis of Lepidosiren are equally clear and convincing, for they show the lateral pairing of filaments taking place in precisely the same way. It is probable that the polarization of threads in the bouquet stage is associated with the presence of a centrosome. In higher plants, on the contrary, in the absence of a centrosome, there is no such polarization, ${ }^{1}$ and it is possible that this may be associated with the telosynaptic method of pairing.

As the primary purpose of this paper was not a study of synapsis, reference will be made to only a few of the recent papers on this subject. In plants, the most important recent paper is that by Digby (1919) on Osmunda. In a very careful investigation of the meiotic and premeiotic divisions in this plant, she emphasizes the fact that the somatic chromosomes in the premeiotic mitoses undergo a split in telophase as a first stage in the process of alveolization, and that in the reverse series of prophase events each chromosome appears to be formed by the reapproximation and fusion of these two split halves or threads. The double thread which every one has observed in the postsynaptic stages of the heterotypic prophase in Osmunda is the crux of the matter for the telosynaptic or parasynaptic interpretation. She interprets it as the same doubling which appears in premeiotic prophases, i.e. as the approximation of the two halves of a univalent spireme, and not the pairing of two univalent filaments. Strong and critical evidence is brought in support of this view, but it unfortunately, probably owing to the nature of the material, lacks one crucial fact which would be absolutely determinative: the number of loops or strands before and after this stage has not been determined, and is probably not possible of determination owing to their arrangement.

The Gordian knot of interpretation might be cut, as Hogben (1920) has done, by assuming constant differences between plants and animals in their meiotic processes. But if one compares Miss Digby's figures (1919, P1. IX, Figs. 47, 48) with Grégoire's (1907) earlier study of Osmunda (Figs. 24,25$)$ on the one hand, and with Janssens's (1905, Pl. III, Fig. I5) on

1 The slight indication of polarization of the threads at one transient stage in Osmunda may represent an intermediate condition. 
Batrachoseps and Agar's (1911, Pl. II, Figs. I2, I3) on Lepidosiren on the other; it seems probable that the difference in opinion regarding these forms is entirely one of interpretation of this stage. We might be inclined on this basis to conclude for the telosynaptic account in all, but for the fact (I) that the telophase and prophase split in the spireme stage of the somatic chromosomes is by no means universal, and (2) that Hogben (1920), whose figures of these stages in Periplaneta are too diagrammatic to be of great value as evidence, nevertheless has the distinct merit of having counted the loops in the bouquet stage in oogenesis and found the diploid number of loops before the pairing and the haploid number afterwards. This appears to show definitely that parasynapsis occurs in Periplaneta.

The Orthoptera among animals were long supposed to show telosynapsis, but the latest account in these insects (Wenrich, 1916) gives strong evidence in favour of parasynapsis in Phrynotettix. Owing to differences in staining and in form, it was possible to trace one pair of chromosomes, and to a less extent two other pairs, into the late semi-resting telophases of spermatogonial divisions and from the earliest heterotypic prophases through the spireme stages to diakinesis. This method of tracing the history of a single chromosome might be supposed to yield absolutely crucial evidence, but we believe the evidence just falls short of this. Wenrich's Figs. 68, 69 (Pl. VI) show the pair of more deeply staining 'A' chromosomes in the early heterotypic prophase, and like all the prophase chromosomes in Phrynotettix he describes them arising, not by the approximation of lateral halves, but as an irregular spiral in a looser matrix. His following Fig. 70 is interpreted as showing the conjugation of the pair of ' $A$ ' chromosomes. But this 'pair', which consists of two parallel beaded threads, is apparently thinner than either of the single spiral 'A' chromosomes of the preceding stage. Important and valuable as this paper is, we cannot therefore regard it as a demonstration of parasynapsis, although the evidence as a whole certainly favours that interpretation.

The nature of synizesis and the occurrence of binucleate pollen mothercells have already been sufficiently discussed in the text.

\section{Chromosome Tristing and Chiasmatypy.}

The cytological phenomenon described by Janssens (1909) as chiasmatypy has been much discussed in recent years as the possible physical basis of the genetical phenomena of crossing-over, particularly in Drosophila (Morgan, 1919). As Wilson (1920) has recently pointed out, the original scheme of Janssens involved four strands in a bivalent chromosome, and Morgan (1919) has shown how on the parasynaptic theory with four parallel strands various distributions of the segments of the four chromatids might result. Wilson, who adheres to the parasynaptic method of heterotype chromosome formation in animals, concludes that Janssens's interpretation of 
chiasmatypy can only be harmonized with the conclusions of other observers regarding the formation of rings by assuming that the chiasmatypy has taken place during a strepsinema stage prior to the straight, longitudinally divided threads from which the rings arise'. He further says (p. 208): 'No observer, so far as I know, has yet seen a process of true crossing-over (recombination) by means of torsion, chiasma formation, and secondary splitting apart.' The torsion described in this paper as occurring during and after the looped stage of the pachynema if followed by breaking across the segments and crossing-over, as appears clearly to be the case in some instances, furnishes exactly the type of redistribution called for, but is obviously quite a different thing from the -chiasmatypy of Janssens. This type of twisting is common enough in plant chromosomes during this period. The absence of evidence of such a process in animal chromosomes leads Wilson to suggest that the crossing-over phenomena may find their basis in some process of torsion during or after synapsis. He even suggests some 'internal process of torsion' or rotation' in the early pachytene stage before the duality of the diplotene thread becomes externally visible. The clear evidence of torsion in plant chromosomes makes it probable that a similar basis for crossing-over will be found in animals where the phenomenon has been analysed genetically on a large scale.

\section{Chromosome Fusions.}

Examination of the literature discloses a considerable number of cases of temporary fusions of various kinds between the chromosomes, both in plants and animals. One of the first cases of a partial or temporary connexion between chromosomes was described by Nawaschin (1912) in root tips of Galtonia. Several investigators have shown that in Galtonia there are eight pairs of chromosomes of varying lengths. Two of those pairs are very small and lie centrally in the chromosome group. Nawaschin calls them satellites. He finds that in prophase they lie on the surface of the nucleolus. Digby (1910) showed that in anaphase they pass to the poles in advance of the other chromosomes. Nawaschin found one pair constantly attached to the inner end of a certain pair of long chromosomes. Tschernoyarow (1914) has found in Najas major, in agreement with Müller (1912), seven pairs of chromosomes which are morphologically distinguishable, one pair being very small. In the heterotypic metaphase Tschernoyarow finds only six pairs of chromosomes, owing to the fusion of these satellites with one of the long pairs. This attachment was also observed in prophase. In this way the discrepancy between Guignard (1899), who çounted twelve chromosomes in the reduction divisions, and Müller (1912), who counted fourteen in somatic mitoses, is explained. This type of temporary fusion appears to be similar to the one described in Lactuca. It differs, however, in the greater uniformity of its occurrence and in the 
presence in other mitoses of a connecting thread between the chromosomes which coalesce in the heterotypic mitosis.

A similar situation exists as regards Vicia Faba. Here Fraser and Snell (1911) counted fourteen chromosomes in the sporophyte, and described in some of the chromosomes constrictions which they regarded as somewhat irregular in character. From the work of Sakamura (1920) it appears that one of these constrictions is constantly present in one pair of chromosomes. He figures (Fig. I6) only six bivalents on the heterotypic spindle and concludes that the number of chromosomes should be reckoned as twelve. But Fraser (1914) figures seven bivalents at this time, although two of them appear to be closely in contact. It therefore appears that, as in Lactuca, there may be failure of coalescence at this time. Probably the real number here should be considered as twelve, since the large M-chromosome pair shows a median as well as a subterminal constriction. Sakamura (p. I 5) finds both these constrictions present in 92 per cent. of cases, but his figures of this and other species of Vicia (in some of which he finds twelve and in some fourteen chromosomes) indicate that there is undoubtedly a considerable amount of variation in these constrictions. Again, Fraser and Snell (1911), although they state that seven is the gametophyte number of chromosomes in $V$. Faba, clearly figure six chromosomes in two cases (Figs. 26 and 28) in the first mitosis within the pollen grain, and doubtfully seven in one figure (Fig. 27) of the same mitosis.

These constrictions in Vicia and in various other forms (the literature is reviewed by Sakamura) are of a somewhat different nature from the coalescences here described in Lactuca. For in the latter there is no indication of connexions in somatic mitoses or heterotypic prophase between the chromosomes which fuse on the heterotypic spindle. The constrictions therefore appear to represent incomplete separation of elements which belong to one chromosome, while the coalescences in Najas and Lactuca are the coming together temporarily of separate chromosomes. These two series of phenomena are undoubtedly closely related, and Galtonia appears to represent a condition intermediate between them. The forms might be arranged in a series, Vicia, Galtonia, Najas, Lactuca, with incomplete separation of the parts of a chromosome on the one hand and only temporary cralescence of independent chromosomes on the other.

A phenomenon closely related to the coalescence of bivalent chromosomes in Lactuca has been described by Kuwada (1919) in Zea Mays, in which the chromosomes are slightly graduated in size. He finds that in starchy varieties of maize the diploid number of chromosomes is twenty, while in certain races of sugar maize the number varies in different individuals. 'Studies of root-tips in these plants showed 20, 2I, or 22, and sometimes 23 or 24 . The number of bivalents in the heterotypic mitosis in these forms was 10,11 , or 12 . This increase in number is believed to be 
the result of transverse segmentation of certain chromosomes. In this connexion it must be mentioned that Collins (1912) on morphological grounds, and as a result of crosses between maize and teosinte (Euchlaena), has developed the interesting theory that maize arose as a hybrid between Euchlaena and some unknown member of the Andropogoneae. This view is by no means proved and is still being controverted by Weatherwax and others. Kuwada, however, believes he has cytological evidence in its support, for he finds that in hybrids between Euchlaena and maize, and also in maize hybrids (Fig. 3, p. 75), some of the bivalents are composed of chromosomes of unequal length. Since the chromosomes of Euchlaena (Io pairs) are longer than those of various Andropogoneae, it is thought that the origin of the unequal pairs is to be accounted for in this way. The presence of eleven and twelve bivalents in some individuals of sugar maize is ascribed to a tendency of two chromosome pairs to undergo constriction and transverse segmentation, these two being descended from Euchlaena chromosomes. These theoretical conclusions are suggestive, but will require much stronger evidence before they can be accepted.

In animal cytology several clear-cut instances of chromosome fusions are known. Cases in Orthoptera will be briefly considered. McClung (1905) described in three species of Hesperotettix a hexad multiple chromosome in the heterotypic prophase formed by the temporary union of a particular tetrad (bivalent chromosome) with the dyad X-chromosome. This union never fails, and there are constant size differences in the hexad of the three species of Hesperotettix studied. Such a hexad has been observed in three Orthopteran families, Acrididae, Locustidae, and Phasmidae. In Hesperotettix speciosus (McClung, 1917) in the male the $\mathrm{X}$-chromosome becomes attached to a euchromosome before synapsis, forming one limb of a V-shaped element with unequal arms. During synapsis the mate of this euchromosome pairs with it and later separates, but throughout maturation the $\mathrm{X}$ remains attached to this chromosome and enters the spermatid nucleus in this condition. In $H$.pratensis the multiple differs from that of $H$. speciosus only in the proportion of its parts, while in the two other species no multiple (i. e. no fusion) occurs. In $H$. viridis the hexad is formed, and also one or two octads may occur by the association of two euchromosome tetrads. The latter process appears to be exactly similar to what occurs in Lactuca. The $\mathrm{X}$ also may remain free. This gives rise to six types of conditions, in which the apparent number of chromosomes varies from nine to twelve due to different combinations of these fusions. But the particular associations are permanent for the individual, the same type of multiple being found throughout all its germ cells. In the related genus Mermiria multiple chromosomes were lacking in two of the species investigated, but in $M$. bivittata a large hexad was formed as in Hesperotettix. In all cases 
the point of union in metaphase is at the ends of the chromosomes, and the phenomenon appears to differ from that in Lactuca only in its greater precision and in its uniformity for the individual.

In the Jamaican Locustidae a similar situation has been described (Woolsey, 1915). In the genus Jamaicana the basal number of chromosomes in the males is thirty-five, but some of the chromosomes unite during meiosis in certain species and individuals. The chromosomes form a graded series, the $\mathrm{X}$ being the largest. In the spermatogonial metaphase two chromosomes of unequal length unite to form a $\checkmark$ while their mates remain separate. This was the condition in seven of the ten individuals belonging to the three species studied. In the three exceptional individuals, one from each species, the conditions were as follows: (I) Two pairs of associated rods forming unequal $\downarrow$ 's. This gave the appearance of thirtyone chromosomes. These $\checkmark$ 's separate after the spermatogonial divisions. (2) One large $\checkmark$ was formed, each arm being composed of a pair of chromosomes united end to end. (3) The two unequal $\vee$ 's were formed, but in the first maturation division they united to form an elongated ring, the $V$ 's separating on the heterotypic spindle. In this genus a multiple is usually accompanied by the X-chromosome. They appear to be attracted, but are not brought into union as in Hesperotettix, Mermiria, and Chorthippus.

The possible relations of these unions of lettuce chromosomes to genetic phenomena as a basis for partial coupling and modification of the Mendelian ratios has been discussed elsewhere (Gates, 1920, p. 221), and need not be considered again at this time.

\section{Chromosome Numbers in Lactuca.}

The chromosome counts of Ishikawa (1916) disclose considerable variation in this genus, the $x$ number ranging from five to twenty-four. There are five pairs of small chromosomes in L. denticulata, L. Keiskeana, $L$. lanceolata and its var. platyphylla. In L. lanceolata the chromosomes apparently differ conspicuously in size. In L. stolonifera Ishikawa finds eight pairs of extremely small chromosomes, and in L. Tamagazvensis eight, often seven, very small bodies. As all the counts were made during the meiotic divisions, the occurrence of seven bodies in some cases points to a fusion of chromosomes similar to that here described in lettuce. In $L$. villosa and L. laciniata there are nine pairs of chromosomes, and they are much larger, apparently agreeing with those of lettuce in their main features, though L. laciniaia has larger chromosomes than $L$. villosa. In $L$. Thunbergiana the chromosomes are similar in size to those of the last two species, but there are twelve pairs of meiotic chromosomes, or frequently eleven, probåbly as a result of temporary coalescence of two pairs during meiosis. L. debilis is $4 x$ as regards chromosome numbers, having twenty- 
four pairs, but is probably not tetraploid, since its chromosomes are small and may have been derived through a transverse segmentation rather than a longitudinal split. A critical study of the chromosomes throughout the genus Lactuca would be a valuable aid in determining the relationships and phylogeny of its species, and would also throw fresh light on the manner in which chromosome numbers and chromosome morphology change from species to species. Numerous recent papers have furnished preliminary materials for such a study of the phylogeny of chromosomes, which will undoubtedly be one of the important future developments in cytology.

\section{SUMMARY.}

In cultivated lettuce (Lactuca sativa, L.) there are nine pairs of chromosomes which form a graded series as regards their length. This is true of both the somatic and the meiotic chromosomes. The same number is found in L. muralis and probably also in L. Scariola.

The method of reduction is telosynaptic, the pachynema forming nine loops, each of which represents a pair of chromosomes attached at one end, the two arms of a loop each constituting a chromosome. These arms frequently twist about each other, before or after the spireme segments into pairs of chromosomes. As these chromosomes condense they may untwist in some cases, but there is some evidence that they frequently break across the twists, producing a straight line of separation between the two longitudinal halves of a bivalent with crossing over of segments from one chromosome to its mate. This differs from the chiasmatypy of Janssens, but furnishes a physical basis for genetical crossing-over.

Synizesis was observed in tapetal nuclei in a few cases. The tapetal cells themselves show several peculiarities. They are loosely arranged even in the presynaptic stages and they show a variety of types, some becoming quadrinucleate and enormously elongated lengthwise of the loculus, others remaining short and thick and often binucleate with very large nuclei. Some of the latter are scalcely distinguishable from pollen mother-cells except by their position. The presence of such transitional forms between pollen mother-cells and tapetal cells probably accounts for the occasional occurrence of synizesis in such cells.

With regard to the nature of synizesis or the synaptic knot, it is found that the process begins with contraction of the nuclear reticulum and is frequently accompanied by the formation of a new precipitation membrane surrounding the reticulum. The contraction is accompanied or followed by a transformation of the reticulum into a spireme, and in the meantime the nuclear membrane undergoes a marked expansion or increase in size. The occurrence of synizesis in tapetal cells emphasizes its unique aspect as a peculiar physiological condition of the nucleus, but since the pairing 
of the homologous chromosomes takes place some time later the significance of the contraction remains obscure.

Binucleate pollen mother-cells were found both before, during, and after synapsis. It seems probable that such cells arise by the breaking down of an incomplete wall between two cells in the archesporium stage.

Occasionally in diakinesis only eight chromosome bivalents were present, and frequently there were only seven or eight separate bodies present on the heterotypic spindle. This was found to be due to a temporary end to end fusion of certain bivalents, usually the shorter ones but occasionally the longest being involved. This phenomenon is also likely to disturb Mendelian ratios, causing partial linkage.

The occasional occurrence of ten chromosomes in diakinesis is due to the separation of the members of one bivalent. On the heterotypic spindle the chromosomes are greatly condensed and there is usually no indication of their bivalent character until the halves begin to separate. Constant differences in size can still, however, be observed.

In the heterotypic telophase the chromosomes are already longitudinally split for the homotypic mitosis.

After the reduction divisions, the cytoplasm of the pollen mother-cells begins to constrict at four points, and these constrictions finally meet in the centre, cutting the contents of the cell into four parts. The young pollen grains so formed alter their shape within the mother-cell wall, becoming roughly heptagonal and then secreting a cell-wall. T'he mothercell wall then breaks down and the wall of the pollen grain ultimately becomes remarkably thickened and sculptured.

The tapetum forms a plasmodium in which the nuclei are more or less completely disintegrated, the process of disintegration beginning before the break-down of the tapetal cell-walls. The plasmodium flows in among the pollen grains, and may contribute directly to the sculpturing of their walls.

\section{LITERATURE CITED.}

Arber, Agnes (1920): Studies on the Binucleate Phase of the Plant-cell. Journ. Roy. Micro. - Soc., 1920, I-2I, I pl., 2 figs.

BeEr, R, and Arber, A. (1915): On the Occurrence of Binucleate and Multinucleate Cells in Growing Tissues. Ann. Bot., xxix. 597-8.

(1919): On the Occurrence of Multinucleate Cells in Vegetative Tissues. Proc. Roy. Soc., B, xci. I-7I, I pl.

Journ. Roy. Micro. Soc., $1920,23-31$.

Collins, G. N. (1912): The Origin of Maize. Journ. Wash. Acad. Sci., ii. 520-3o, 
Davis, B. M. (1910): The Reduction Divisions of Oenothera biennis. Ann. Bot., xxiv. 64I-5I, 2 pls.

Digby, L. (1909): Observations on 'Chromatin Bodies' and their Relation to the Nucleolus in Galtonia candicans, Decsne. Ann. Bot., xxiii. 49I-502, 2 pls.

(1910): The Somatic, Premeiotic, and Meiotic Nuclear Divisions of Galtonia candicans. Ibid., xxiv. $727-57,5$ pls.

(1912): The Cytology of Primula Kervensis and of other Related Primula Hybrids. Ibid., xxvi. $357-88,4$ pls.

(1914): A Critical Study of the Cytology of Crepis virens. Arch. f. Zellforsch., xii. 97-I 46, 3 pls.

(1919): On the Archesporial and Meiotic Mitoses of Osmunda. Ann. Bot., xxxiii. I $35-72,5$ pls., I fig.

FArmer, J. B., and Moore, J. E. S. (1905): On the Meiotic Phase (Reduction Divisions) in Animals and Plants. Quart. Journ. Micro. Sci., xlviii. 489-557, Pls. 34-4I.

FARR, Clifford H. (1916) : Cytokinesis of the Pollen Mother-cells of certain Dicotyledons. New York Bot. Garden, vi. 253-3 I 7, 3 pls., I fig. 95, 3 pls.

FARr, WANDA K. (1920): Cell-division of the Pollen Mother-cell of Cobaea scandens alba. Bull. Torr. Bot. Club, xlvii. $3^{2} 5^{-3} 8$, I pl.

Fraser, H. C. I. (1914): The Behaviour of the Chromatin in the Meiotic Divisions of Vicia Faba. Ann. Bot., xxviii. $635-4^{2}, 2$ pls. $845-55,2$ pls.

Gates, R. R. (1907): Pollen Development in Hybrids of Oenothera lata $\times$ O. Lamarckiana, and its Relation to Mutation. Bot. Gazette, xliii. 8I-I I5, 3 pls.

(1908): A Study of Reduction in Oenothera rubrinervis. Ibid., xlvi. I-34, 3 pls.

(1911) : Pollen Formation in Oenothera gigas. Ann. Bot., xxv. 909-40, 4 pls.

(1920): A Preliminary Account of the Meiotic Phenomena in the Pollen Mothercells and Tapetum of Lettuce (Lactuca sativa). Proc. Roy. Soc., B, xci. 2I6-223.

Grégorre, V. (1907): La formation des genini hétérotypique dans les végétaux. La Cellule, xxiv. $369-420,2$ pls.

Gregory, R. P. (1905) : The Abortive Development of the Pollen in certain Sweet-peas (Lathyrus odoratus). Proc. Camb. Phil. Soc., xiii. $\mathrm{I}_{4}^{8-56,2} \mathrm{pls}$.

Guignard, L. (1899) : Le développement du pollen et la réduction chromatique dans le Naias major. Arch. d'Anat. Micros.. ii. 455-509, 2 pls.

Holmgren, I. (1919): Zytologische Studien über die Fortpflanzung bei den Gattungen Erigeron und Eupatorium. Kungl. Svensk. Vetenskapsakad. Handl., No. 7, lix. 3-I I 8, 24 figs.

Ishikawa, M. (1916): A List of the Number of Chromosomes. Bot. Mag., Tokyo, xxx. 404-5I, $3^{2}$ figs.

Janssens, F. A. (1909) : La théorie de la Chiasmatypie. La Cellule, xxv. 389-4I I, 27 figs., 2 pls.

Juel, H. O. (1915): Untersuchungen über die Auflösung der Tapetenzellen in den Pollensäcken 'der Angiospermen. Jahrb. wiss. Bot., 1vi. 337-64, 5 pls

Koernicke, M. (1902) : Über Ortsveränderung von Zellkernen. Sitz-Ber. Niederrhein. Ges. Nat.п. Heilk. zu Bonn, I90 r, I 4-25.

KuwadA, Y. (1919): Die Chromosomenzahl von Zea Mays, L. Journ. Coll. Sci. Imp. Univ. Tokyo, xxxix. I-I $4^{8}$, 2 pls., 4 figs.

Lawson, A. A. (1911): The Phase of the Nucleus known as Synapsis. Trans. Roy. Soc., Edin., xlvii. $59 \mathrm{r}-60_{4}, 2$ pls.

McAllister, F. (1913): On the Cytology and Embryology of Smilacina racemosa. Trans. Wisconsin Acad. Sci., xvii. 599-660, 3 pls.

McClung, C. E. (1905): The Chromosome Complex of Orthopteran Spermatocytes. Biol. Bull., ix. 304-40, 2 I figs.

(1917): The Multiple Chromosomes of Hesperotettix and Mermiria (Orthoptera). Journ. Morph., xxix. 519-605, 8 pls.

MASCRÉ, M. (I9I9): Nouvelles remarques sur le rôle de l'assise nourricière du pollen. Compt. Rend. Acad. Sci. Paris, clxviii. I 2 I 4-16, 
Morgan, T. H. (1919): The Physical Basis of Heredity, 305 pp., I 7 figs. Lippincott: Philadelphia and London.

NAKAo, M. (1911): Cytological Studies on the Nuclear Division of the Pollen Mother-cells of some Cereals and their Hybrids. Journ. Coll. Agr. Sapporo, iv. I 73-90, 4 pls.

Nawaschin, S. (1912): [Chromosomes of Galtonia candicans. Russian]. Bull. de l'Acad. Imp. d. Sci., St. Petersburg, vi. $373-85,5$ figs.

Olive, E. W. (1907): Cytological Studies on Ceratiomyxa. Trans. Wisconsin Acad. Sci., xv. 75374, I pl.

Pickers, F. L. (1916): The Wandering Tapetal Nuclei of Arisaema. Amer. Journ. Bot., iii. $46 \mathrm{I}-9$, I pl, 8 figs.

Rosenberg, O. $(1909 a)$ : Zur Kenntnis von den Tetradenteilungen der Compositen. Sivensk. Bot. Tidskrift, iii. $64-77$, I pl.

$(19096)$ : Cytologische und morphologische Studien iiber Drosera longifolia $\times$ rotundifolia. Kungl. Svensk. Vetenskapsakad. Handl., xliii. I-64, 4 pls.

Sakamura, Tetsu (1916) : Ubber die Beeinflussung der Zell- und Kernteilung durch die Chloralisierung, mit besonderer Riicksicht auf das Verhalten der Chromosomen. Bot. Mag., Tokyo, xxx. $375-99$, I pl.

(1920) : Experimentelle Studien iiber die Zell- und Kernteilung, mit besonderer Rücksicht anf Form, Grösse und Zahl der Chromosomen. Journ. Coll. Sci. Imp. Univ. Tokyo, xxxix. I-22 I, 7 pls., 24 figs.

Tischler, G. (1915): Die Periplasmodiumbildung in den Antheren der Commelinaceen und Ausblicke auf das Verhalten der Tapetenzellen bei den ïbrigen Monokotylen. Jahrb. wiss. Bot., lv. 53-9o, I pl., 7 figs.

Tschernoyarow, M. (1914): Über die Chromosomenzahl und besonders beschaffene Chromosomen im Zellkerne von Najas major. Ber. d. d. Bot. Gesell., xxxii. 4II-I6, I pl.

West, C., and Lechmere, A. E. (1915): On Chromatin Extrusion in Pollen Mother-cells of Lilium candidum, Linn. Ann. Bot., xxix. 285-9r, I pl.

Wilson, E. B., and Morgan, T. H. (1920): Chiasmatype and Crossing-over. Amer. Nat., liv. I 93-2 I9, 8 figs.

Winge, O. (1917) : The Chromosomes, their Numbers and General Importance. Comptes rendus des Trav. du Lab. Carlsberg, xiii. I 3 I-275, 46 ligs., I pl.

Woolsey, Carrie I. (1915): Linkage of Chromosomes correlated with Reduction in Numbers among the Species of a Genus, also with a Species of the Locustidae. Biol. Bull., xxviii. $163-87,6$ pls.

Yamaha, Gihei (1920): Beobachtungen über die Zellteilung in den Archesporen und Sporenmutterzellen von Psilotum triquetrum Sw., mit besonderer Rïcksicht auf die Zellplattenbildung. Bot. Mag., Tokyo, xxxiv. I $17-29,20$ figs.

\section{EXPLANATION OF PLATES XVI-XIX.}

Illustrating Dr. Gates and Miss Rees's paper on a Cytological Study of Pollen Development in Lactuca.

All the figures were drawn with the camera lucida under a $1 /$ I $2^{\prime \prime}$ imm. homog. Koristka Ap. N. I 30 with Comp. Oc. 12 or Comp. Oc. 6, giving magnifications of $\times 3,000$ and $\times 1,500$ respectively.

Figs. I-I $7,55,56,64,70-72,74,79$, and $82-85$ were taken from the rogue.

All other figures from the type.

\section{PLATE XVI.}

Fig. I. Portion of loculus showing pollen mother-cells with nuclei in resting stage. Tapetal cells uninucleate. $\times$ I,500. 
Fig. 2. Loculus at later stage. Pollen mother-cells in postsynaptic spireme stage. One mother-cell is binucleate. Tapetal cells with from one to four nuclei. $\times 1,500$.

Fig. 3. Loculus at similar stage to Fig. 2, one tapetal cell showing two nuclei in synizesis. $\times \quad$ I,500.

Fig. 4. Portion of loculus showing variation in shape and size of tapetal cells at opposite sides of loculus. $\quad \times \quad$, 500 .

Fig. 5. Pollen mother-cell with nucleus in resting condition. $\times 3,000$.

Fig. 6. Pollen mother-cell showing the beginning of contraction of the reticulum at one point. $\times 3,000$.

Fig. 7. Slightly later stage than Fig. 6. The nuclear membrane has broken down at one side. First indication of transformation from reticulum to spireme. $\times 3,000$.

Fig. 8. Pollen mother-cell nucleus showing final stage of contraction. Membrane plainly visible, surrounding the reticulum. $\times 3,000$.

Fig. 9. Similar stage to Fig. 8, but membrane less apparent. Reticulum still connected to nuclear membrane by numerous fine threads. $\times 3,000$.

Fig. I0. Similar stage showing both reticular membrane and connecting threads. $\quad \times 3,000$

Fig. I I. Pollen mother-cell nucleus in typical synizesis stage. $\times 3,000$.

Fig. I 2. Pollen mother-cell nucleus showing spireme emerging from the synaptic knot. $\quad \times 3,000$.

Fig. 13. Similar stage to Fig. 12, but showing cytomyxis. Extrusion of chromatic material has taken place from the smaller cell on the left. $\times 3,000$.

Fig. I4. Binucleate pollen mother-cell, both nuclei in presynaptic resting stage. $\quad \times 3,000$.

Fig. I 5. Binucleate pollen mother-cell. Both nuclei about to form synaptic knot. $\times 3,000$.

Fig. I6. Binucleate pollen mother-cell, nuclei in spireme stage. $\quad \times 3,000$.

Fig. I7. Binucleate pollen mother-cell, probably postsynaptic. $\times 3,000$.

\section{PLATE XVII.}

Fig. I8. Early postsynaptic spireme stage, thread nearly continuous, a few free ends visible, nuclear membrane indistinct. $\times 3,000$.

Figs. 19-26. Various stages showing looping of the portions of the spireme to form finally nine bivalent chromosomes. $\times 3,000$.

Fig. 27. Slightly later stage; portions of the spireme, in the form of loops, having broken off. $\times 3,000$.

Figs. 28, 29. Further stages of the segmentation of the spireme. Nine segments can be counted. $\times 3,000$.

Fig. 30. Segmentation completed. Note the four long twisted bivalents and five shorter and more condensed. $\times 3,000$.

Figs. $3^{I-3}$. Further stages of the progressive condensation of the nine bivalent chromosomes, showing also the torsion. $\times 3,000$.

Fig. 37. Diakinesis with ten chromosomes. The two marked ' $a$ ' probably represent the two halves of a single original bivalent chromosome. $\times 3,000$.

Figs. $3^{8}, 39$. Diakinesis. Nearly all trace of the bivalent nature of the chromosomes is lost. $\times 3,000$.

Fig. 40. Diakinesis. One bivalent chromosome almost split into its component halves. $\times 3,000$.

Figs. 4I-44. Diakinesis. Nine bivalent chromosomes. $\times 3,000$.

Fig. 45. Diakinesis. Note ţhreads connecting two pairs of bivalents. $\times 3,000$.

Fig. 46. Diakinesis. Two of the longest bivalents fused end to end. $\times 3,000$.

Figs. 47,48 . Diakinesis. Only eight bivalents in each, no definite evidence of fusion. $\times 3,000$.

Fig. 49. Single bivalent chromosome, showing the loops. $\times 3,000$.

Fig. 50. Heterotypic metaphase in polar view. Only seven independent chromosomes, but those marked ' $a$ ' represent fused pairs of bivalents. $\times 3,000$.

Fig. 51. Heterotypic metaphase in polar view. Eight chromosomes, one clearly representing two bivalents fused end to end. $\times 3,000$.

Fig. 52. Metaphase showing nine bivalents. Note points of attachment to spindle fibres. $\times 3,000$.

Figs. 53, 54. Metaphase with eight bivalents. Note again points of attachment, and the ring of dark staining material in Fig. 54. $\times$ 3,000. 


\section{PLATE XVIII.}

Figs. $37 a-55 a$. Chromosome bivalents taken from the correspondingly numbered figures in Plate XVII, and arranged in rows to show relative lengths and sizes. $\times 3,000$.

Fig. 55. Metaphase of heterotype division in polar view showing nine bivalents. Note denser surrounding layer of cytoplasm. $\times 3,000$.

Fig. 56. Similar stage in side view. Note again denser area of cytoplasm. $\times 3,000$.

Fig. 57. Early anaphase. Whole chromosomes beginning to separate from each other. $\times 3,000$.

Fig. $5^{8}$. Later anaphase, showing how the bivalents separate. All but the pairs have split apart. See p. $386 . \times 3,000$.

Fig. 59. Later anaphase, cut. $\times 3,000$.

Fig. 6o. Telophase. Nine univalent chromosomes in each daughter nucleus. Most of the chromosomes have already split. $\times 3,000$.

Fig. 6r. Abnormal telophase. Nuclei strongly hyperchromatic. Note temporary plate forming in spindle, and also chromatic bodies in cytoplasm. $\times 3,000$.

Fig. 62. Telophase. Chromosomes becoming transformed into a reticulum. Note chromatic bodies in cytoplasm. $\times 3,000$.

Fig. 63. Somatic cell from root tip. Anaphase showing eighteen chromosomes varying greatly in length in each group. Note vacuolate nature of cytoplasm. $\times 3,000$.

Fig. 64. Somatic nucleus in prophase from tissue of young bud, showing chromosomes of various lengths. $\times 3,000$.

\section{PLATE XIX.}

Fig. 65. Abnormal pollen mother-cell in heterotypic telophase stage, showing supernumerary nuclei. $\times 3,000$.

Fig. 66. Pollen mother-cell showing tetrad formation. Note invagination of cytoplasm to form the pollen grains. $\times 3,000$.

Fig. 67. Similar stage to above, but the furrows have progressed farther and they cut across the spindle fibres. Fourth grain indicated by dotted lines. $\times 3,000$.

Fig. 68. Tetrad after pollen grains have separated from each other, but are still enclosed in mother-cell. Note heptagonal shape of grains and beginning of thickening of the walls. $\times 1,500$.

Fig. 69. Abnormal tetrad in later stage, after mother-cell wall has disappeared. Note that only three pollen grains are present and central one is binucleate. $\times 3,000$.

Fig. 70. Pollen grain showing thickenings of the wall. $\times 3,000$.

Fig. 7I. Pollen grain with still thicker wall and 'frills' in process of formation. $\times 3,000$.

Fig. 72. Portion of loculus with three mature pollen grains. Note sculpturing of grains, and plasmodium formed by breaking down of tapetal cells. $\times$ I, 500 .

Fig. 73. Small tapetal cell with two nuclei. Pollen mother-cells in diakinesis. $\times \mathrm{I}, 500$.

Fig. 74. Tapetal cell, with two nuclei in synizesis. Mother-cells in early spireme stage. $\times 3,000$.

Figs. 75, 77. Binucleate tapetal cells. Mother-cells of loculus in diakinesis. $\times \mathbf{I}, 500$.

Fig. 76 . Binucleate tapetal cell on larger scale, both nuclei in prophase stage of second division. $\times 3,000$.

Fig. 78. Single nucleus of binucleate tapetal cell. Note chromatic bodies. $\times 3,000$.

Fig. 79. Binucleate tapetal cell from end of loculus. Note only two chromatic bodies to each nucleus. $\times \mathbf{I}, 500$.

Fig. 8o. Quadrinucleate tapetal cell from middle of loculus. Note length of cell. $\times \mathbf{I}, 500$.

Fig. 8I. Quadrinucleate tapetal cell from end of a loculus. Note shape and compare with Fig. 8o. The two central nuclei are breaking down. $\times$ I, 500 .

Fig. 82. Trinucleate tapetal cell. Two nuclei in synizesis. Central one apparently result of fusion of two nuclei each in spireme stage. $\times 3,000$.

Figs. $83^{-86}$. Various stages in degeneration of tapetal cells. Note fragmentation and degeneration of nuclei and disintegration of cell-walls. Mother-cells of Figs. $8_{3}, 85$, and 86 in tetrad stage. Fig. 84 , pollen grains formed. $\times \mathrm{I}, 500$. 
Anrals of Botany,

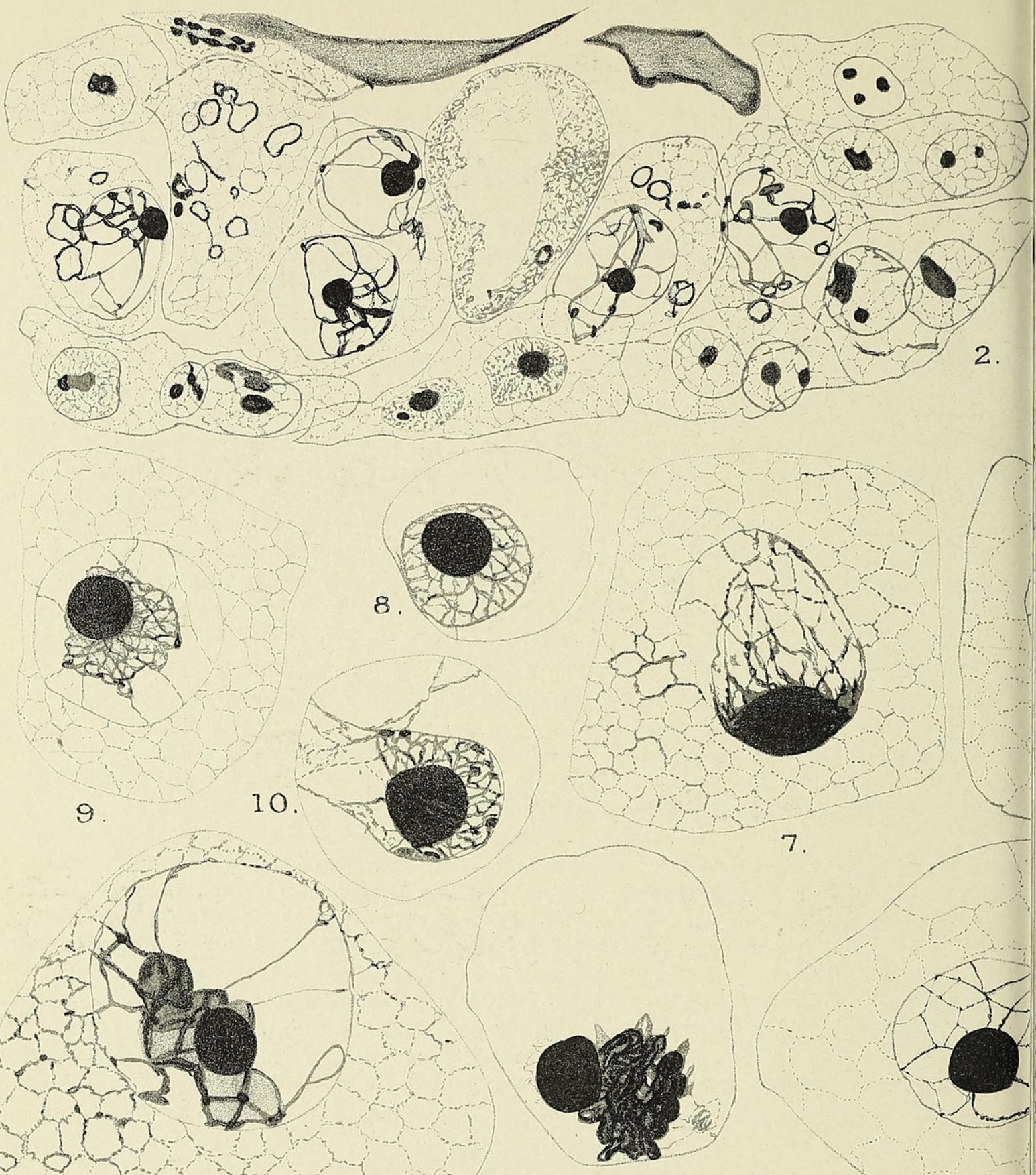

12.

11.

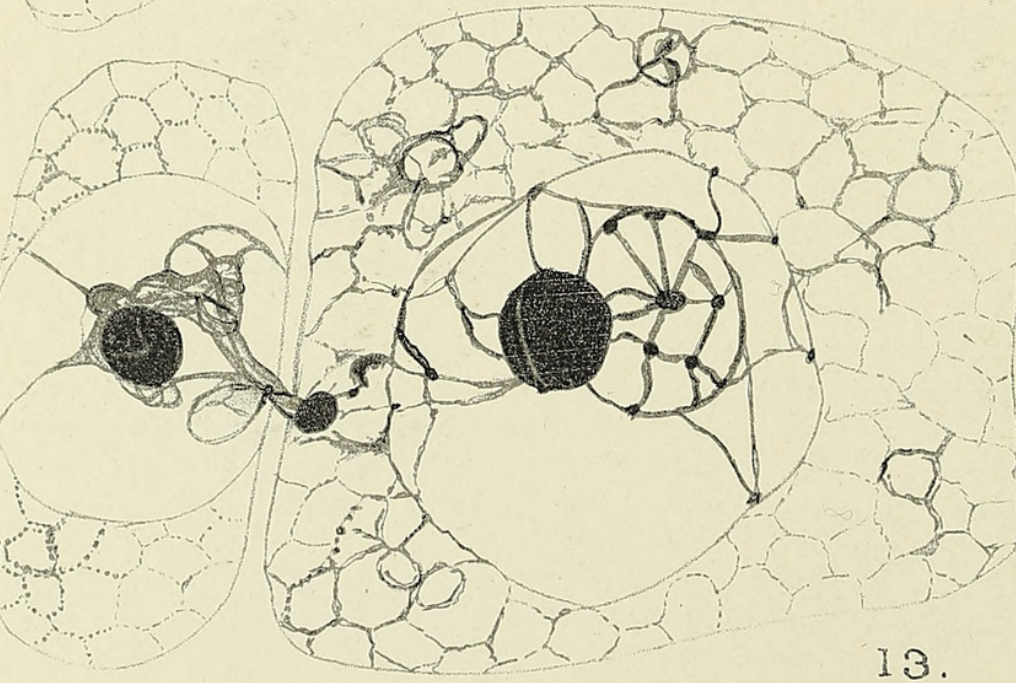

14.

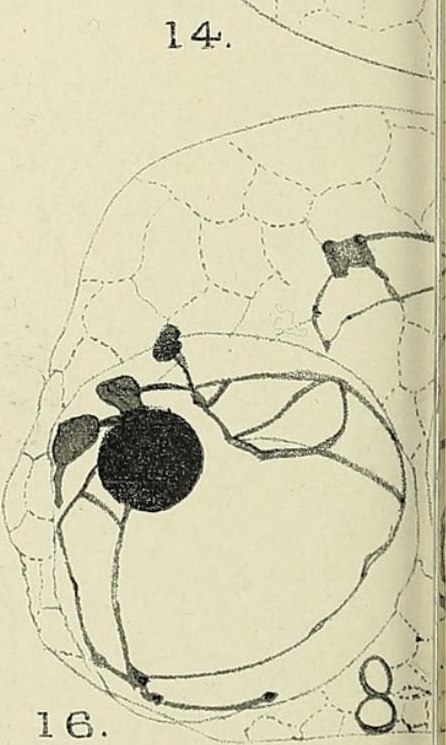

GATES AND REES - LACTUCA. 
Vol. XXXV, PL. XVI.

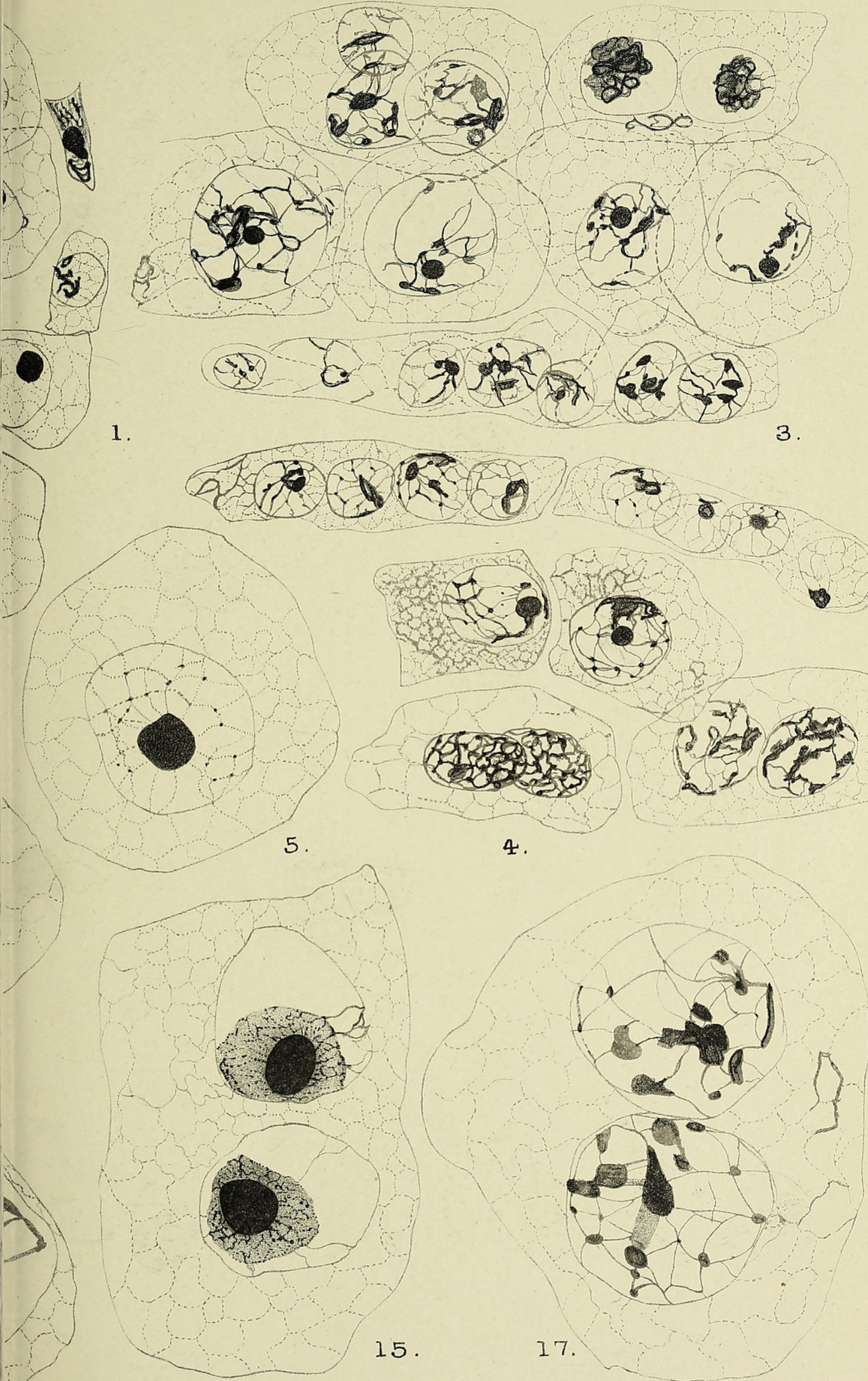



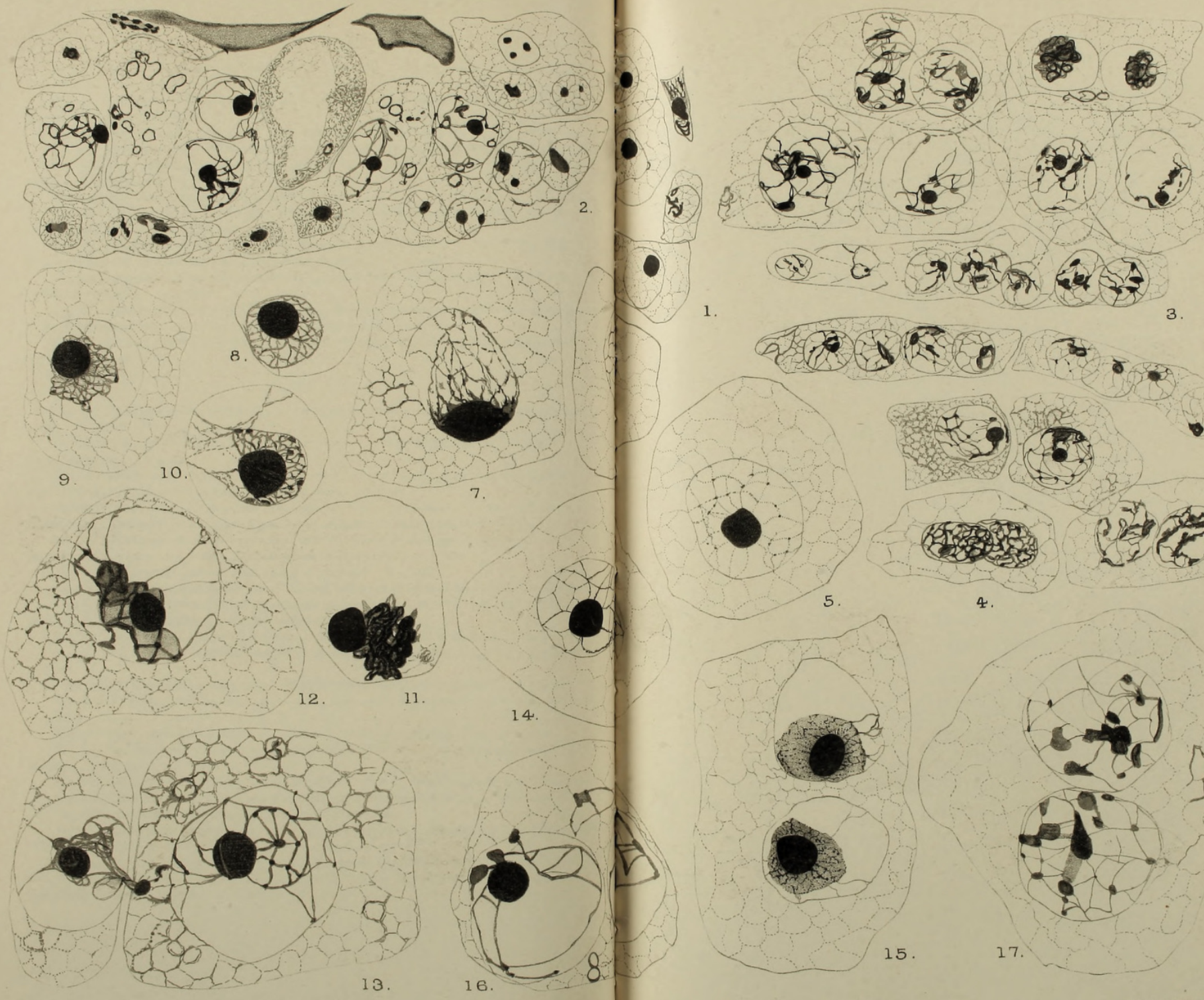

1
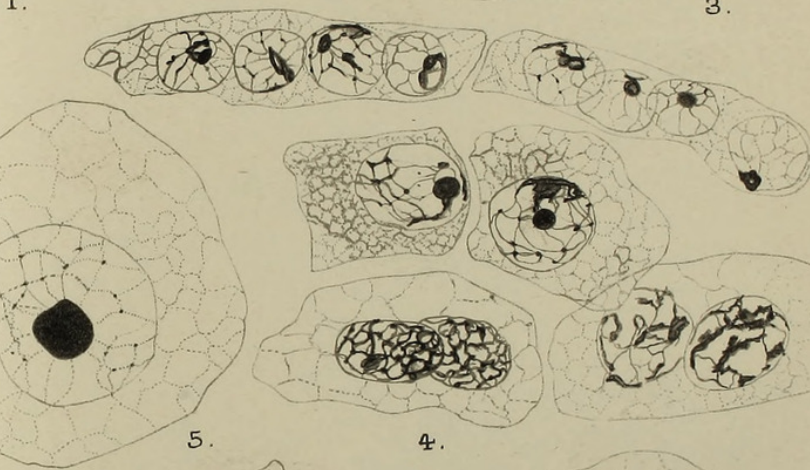

GATES AND REES - LACTUCA. 

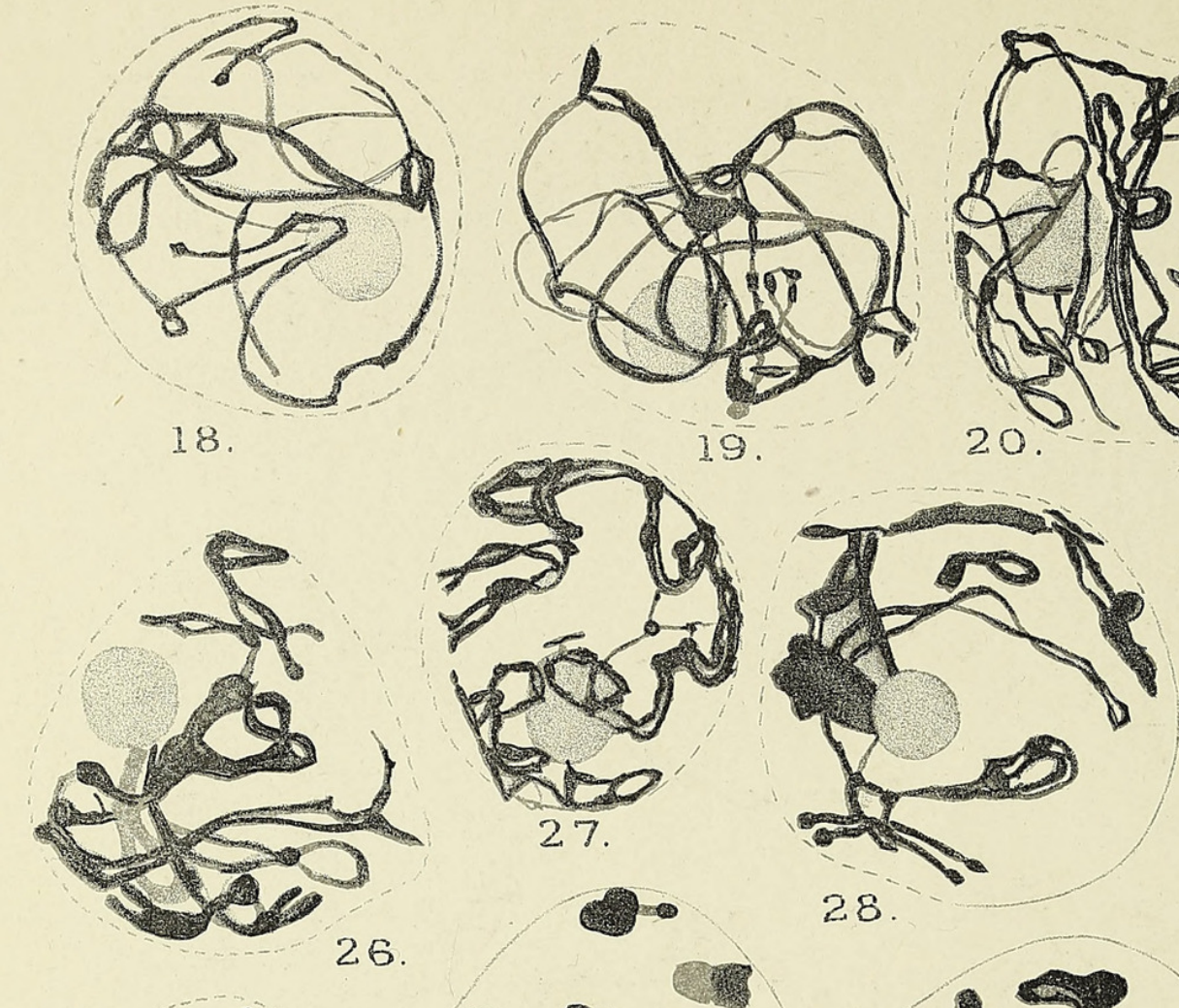

28.

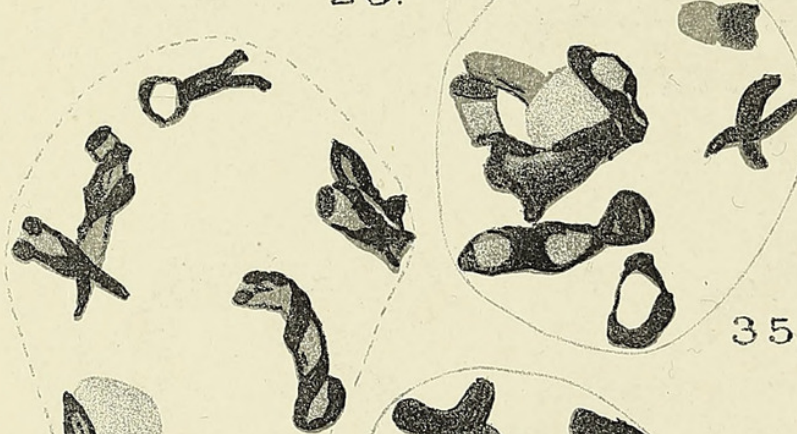

35.
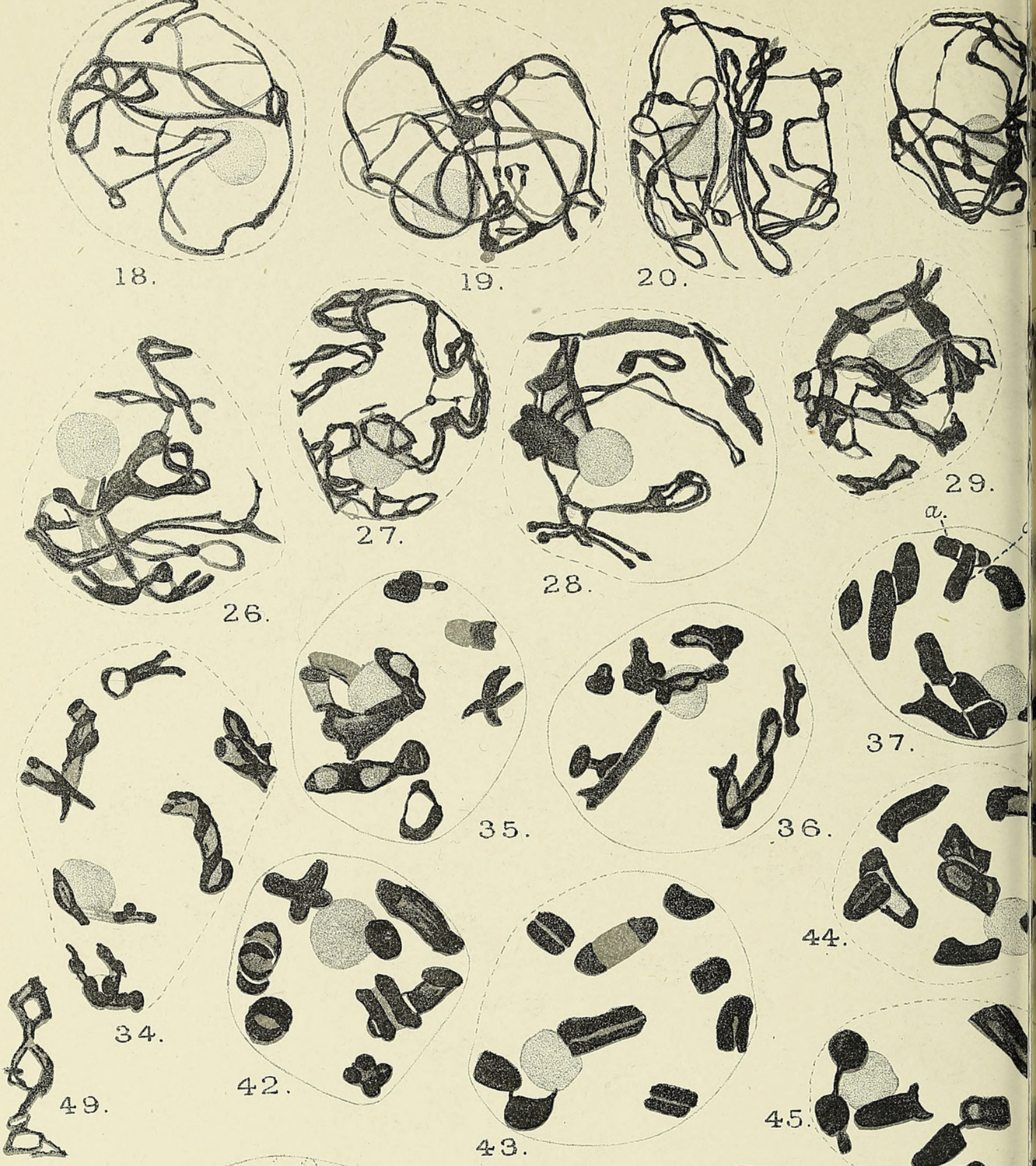
Vol. XXXV, PL.XVII.
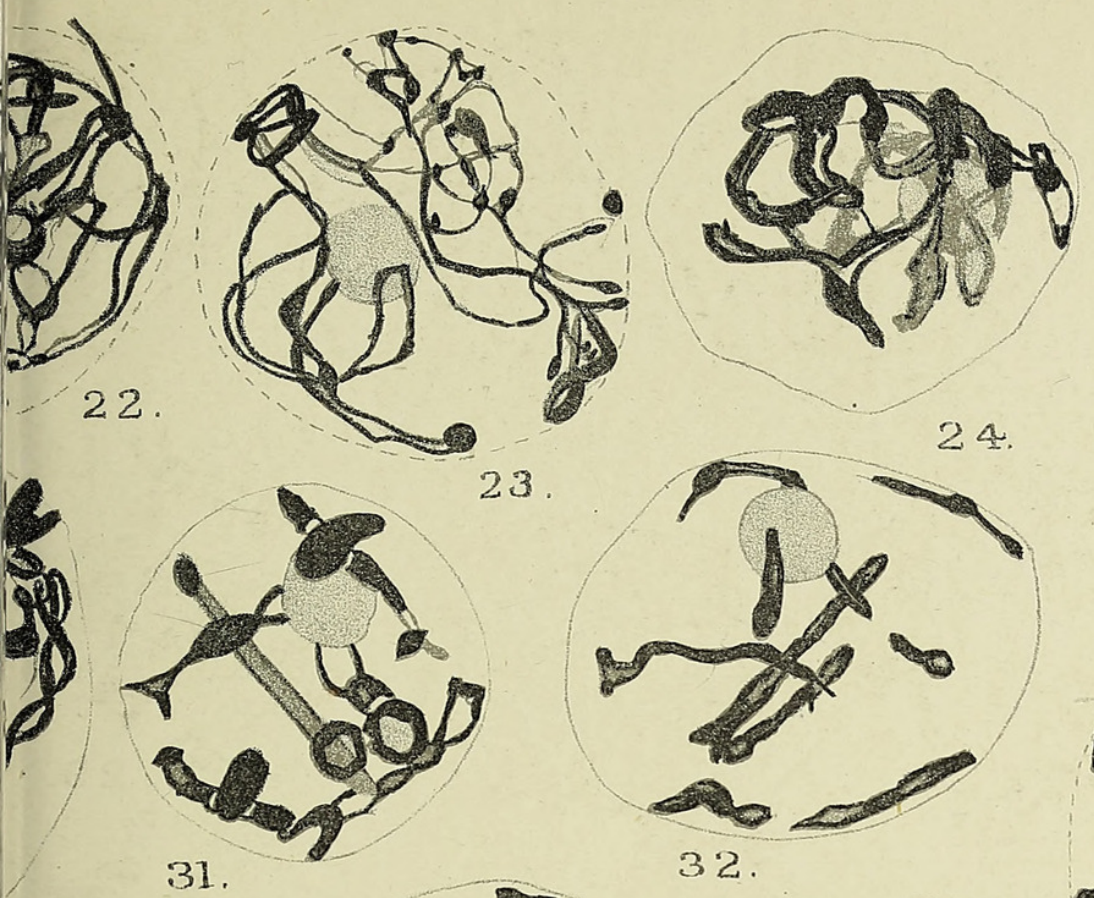

23.

31.

$11+\infty$
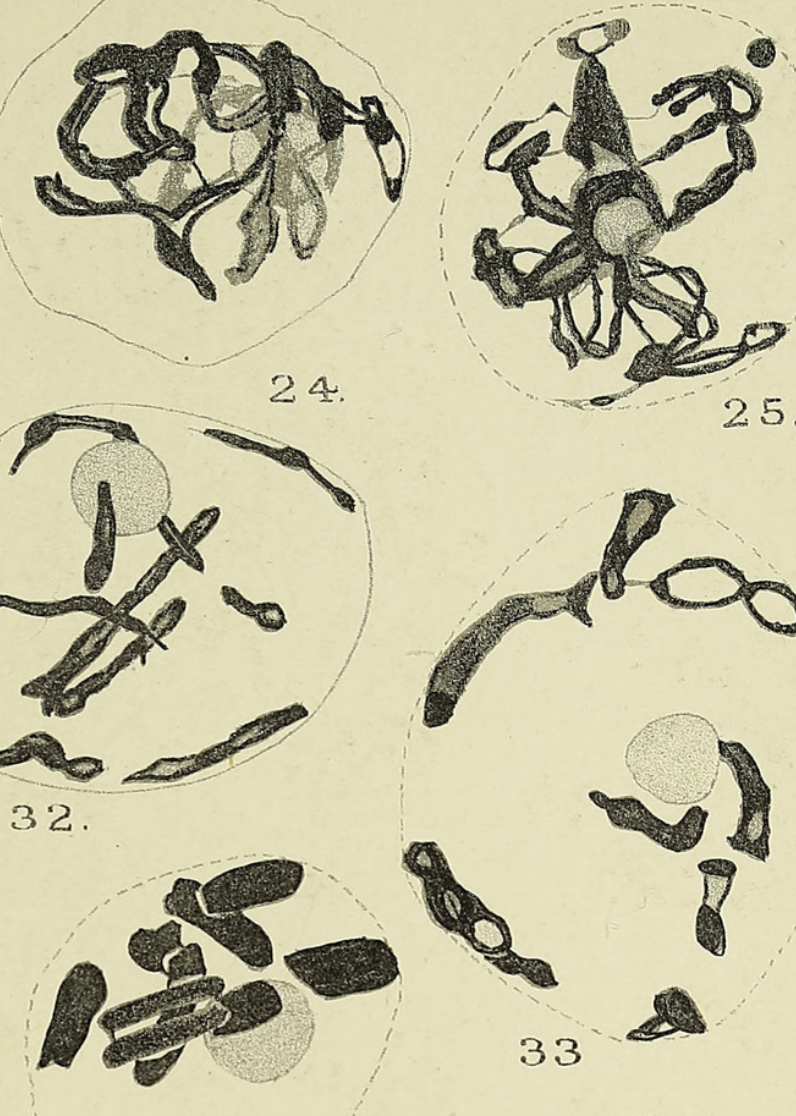

38.

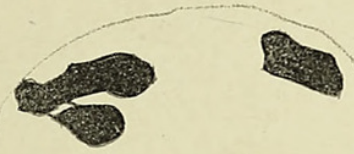
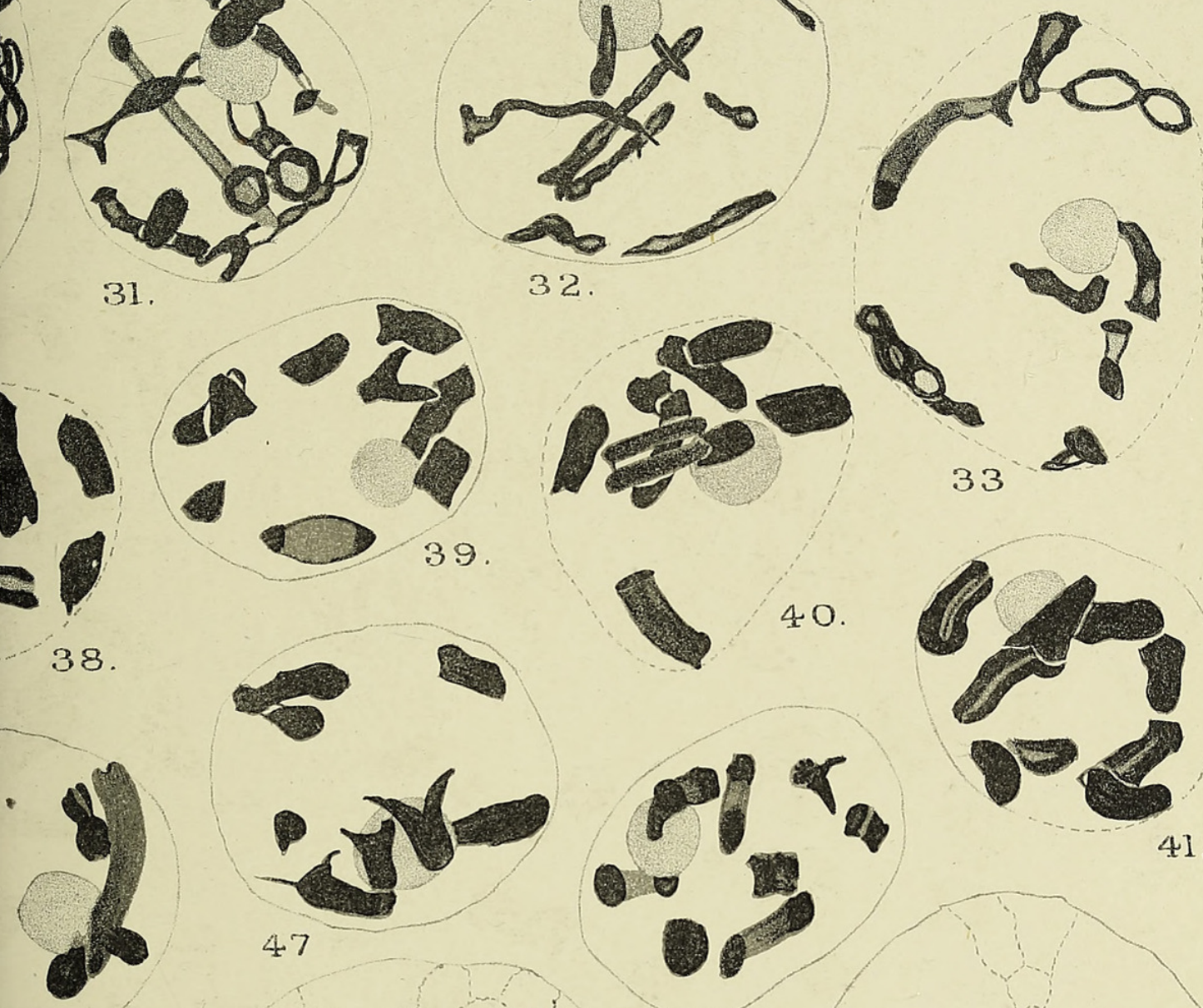

47

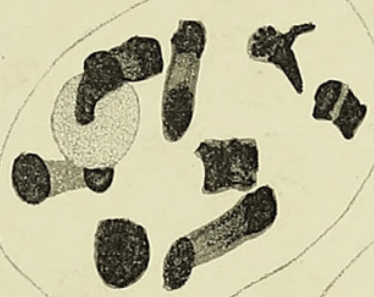

(2)

46
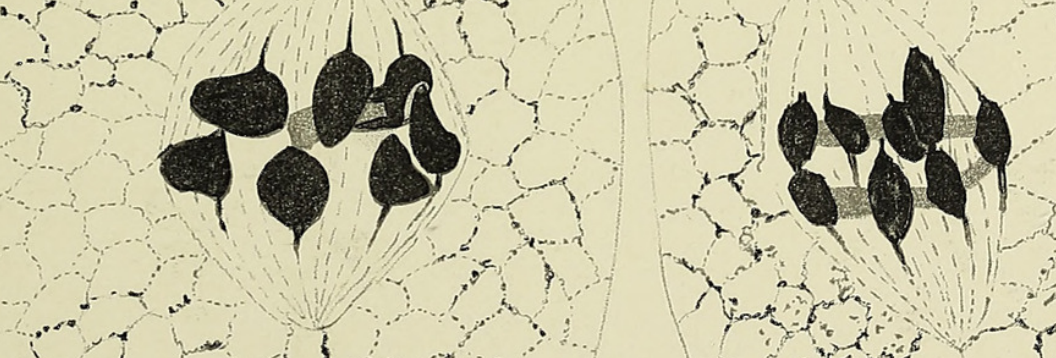

C 13

48.

53.

54. 
7)

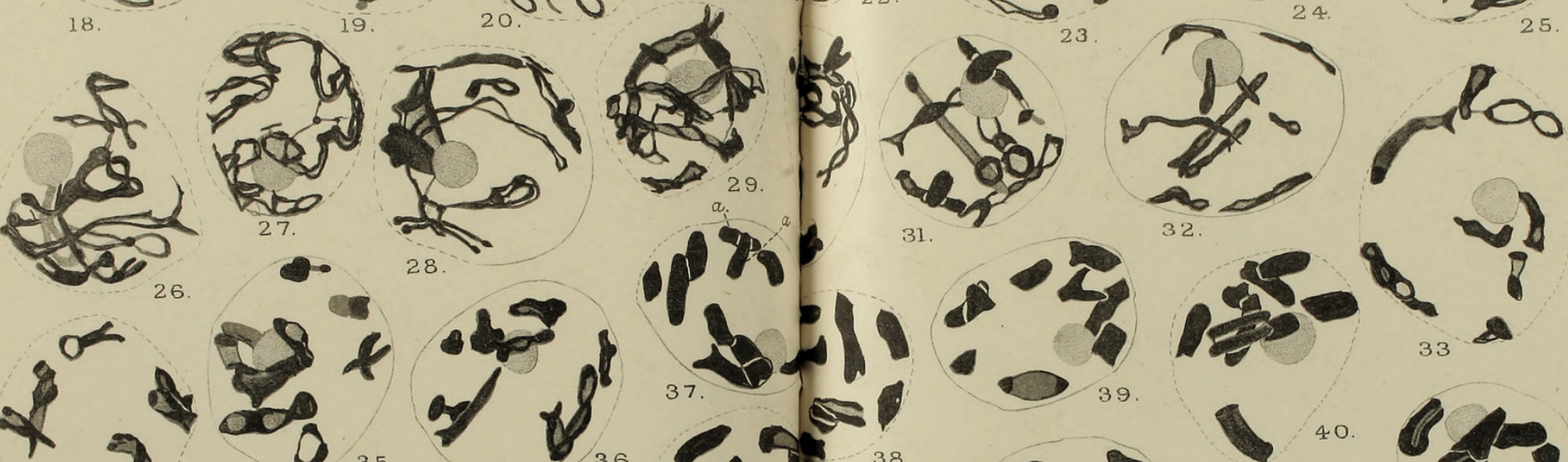

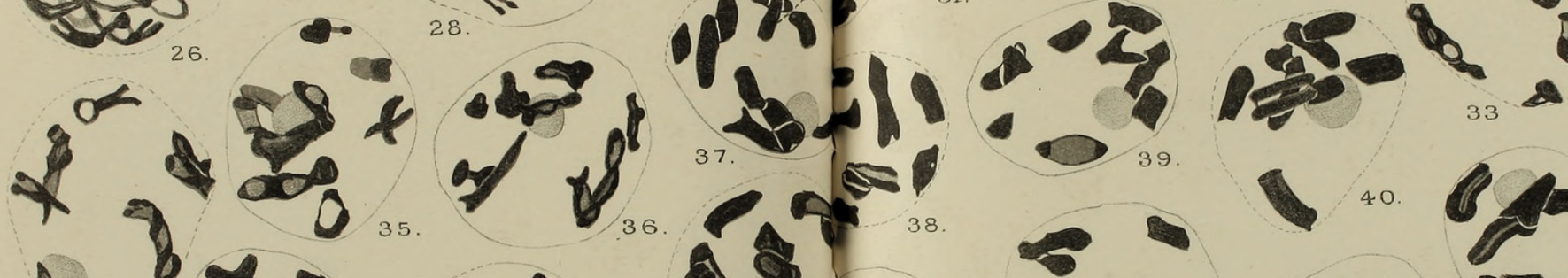

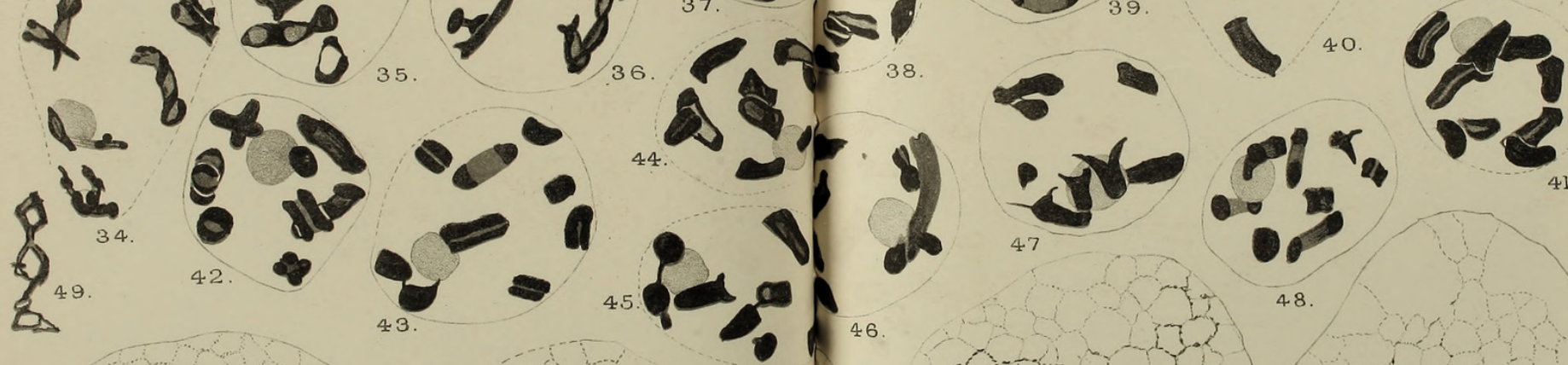

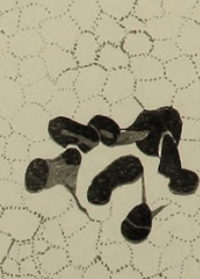

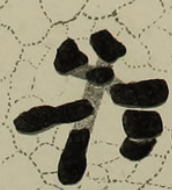
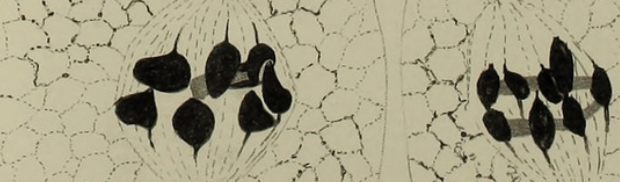
6110100, 11: 11080010 180.90 IOIrarar

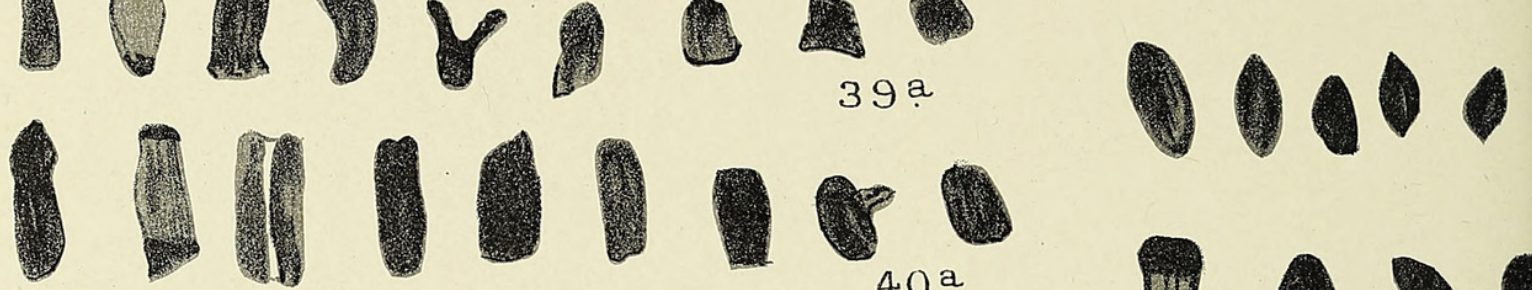
BAOARED of $11 \times 0=0$

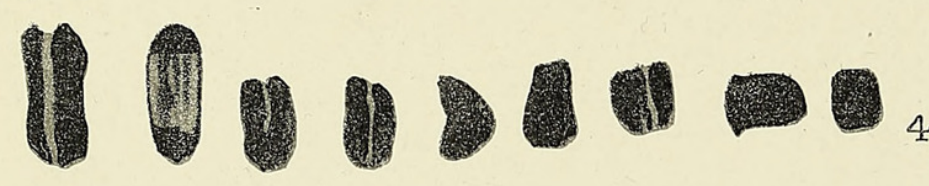
1018000 blogedo. Jinto: 200\% orrenis. 


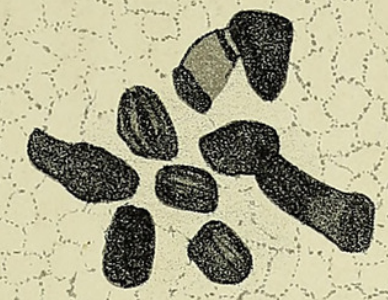

55.
56.
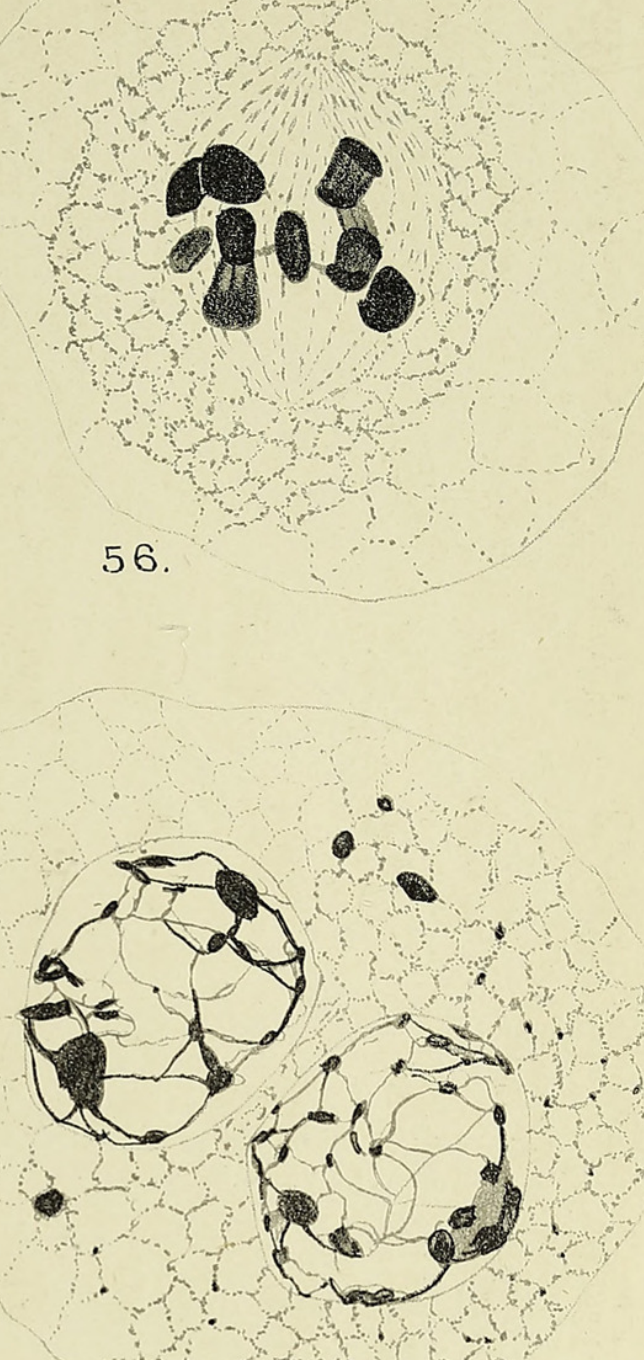

10
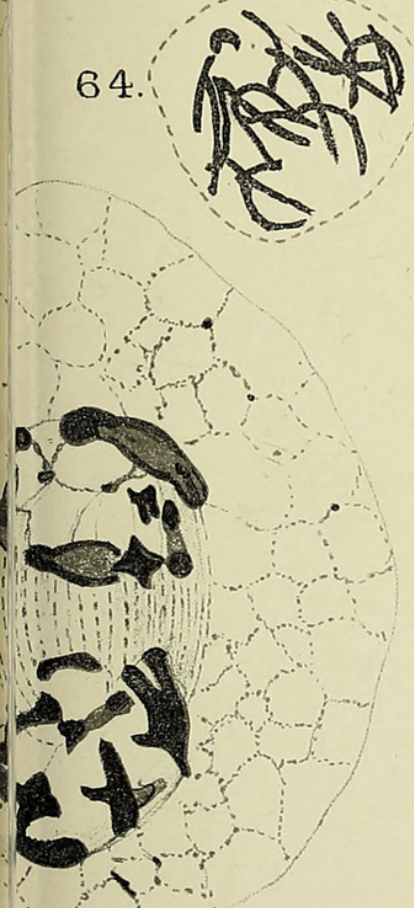

62

59
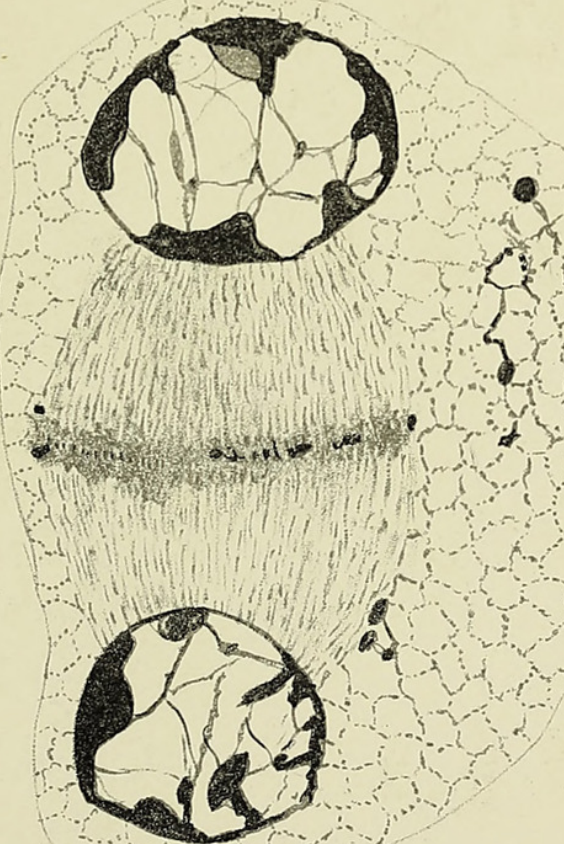

61.

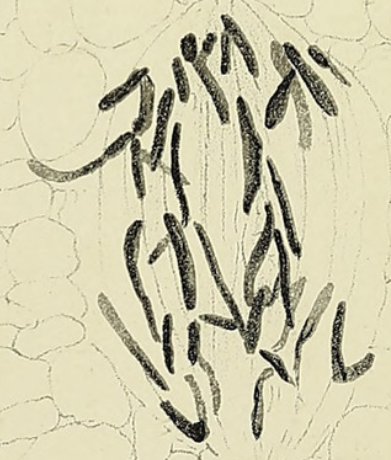

63. 

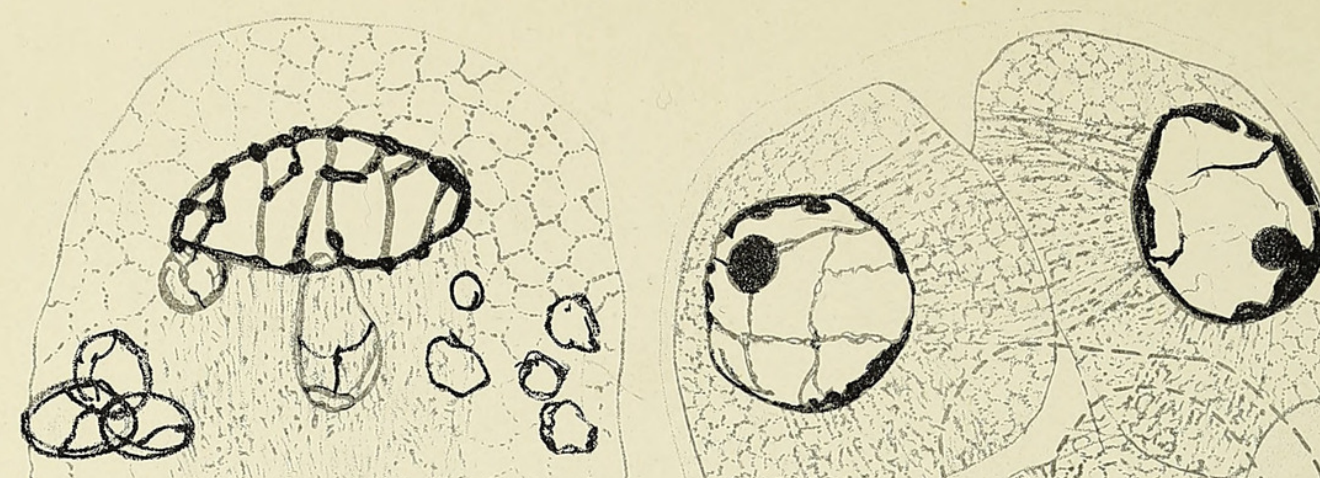

65

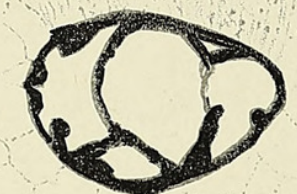

67
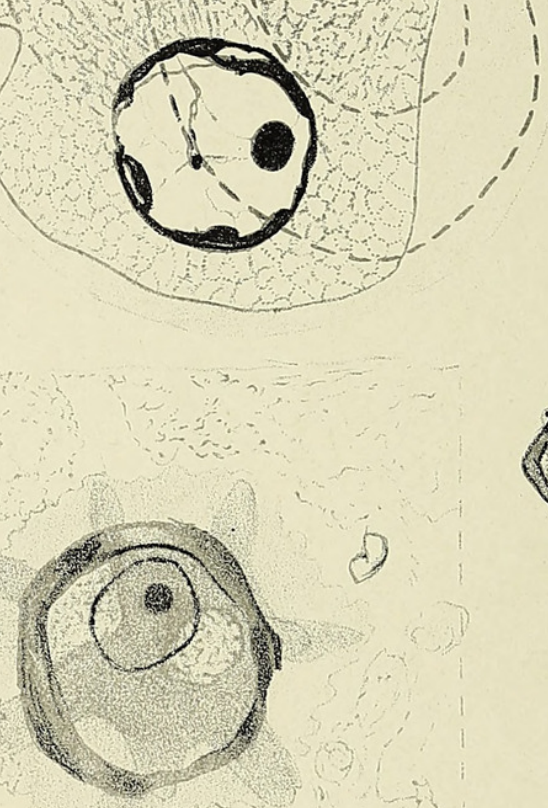

(3)

73.
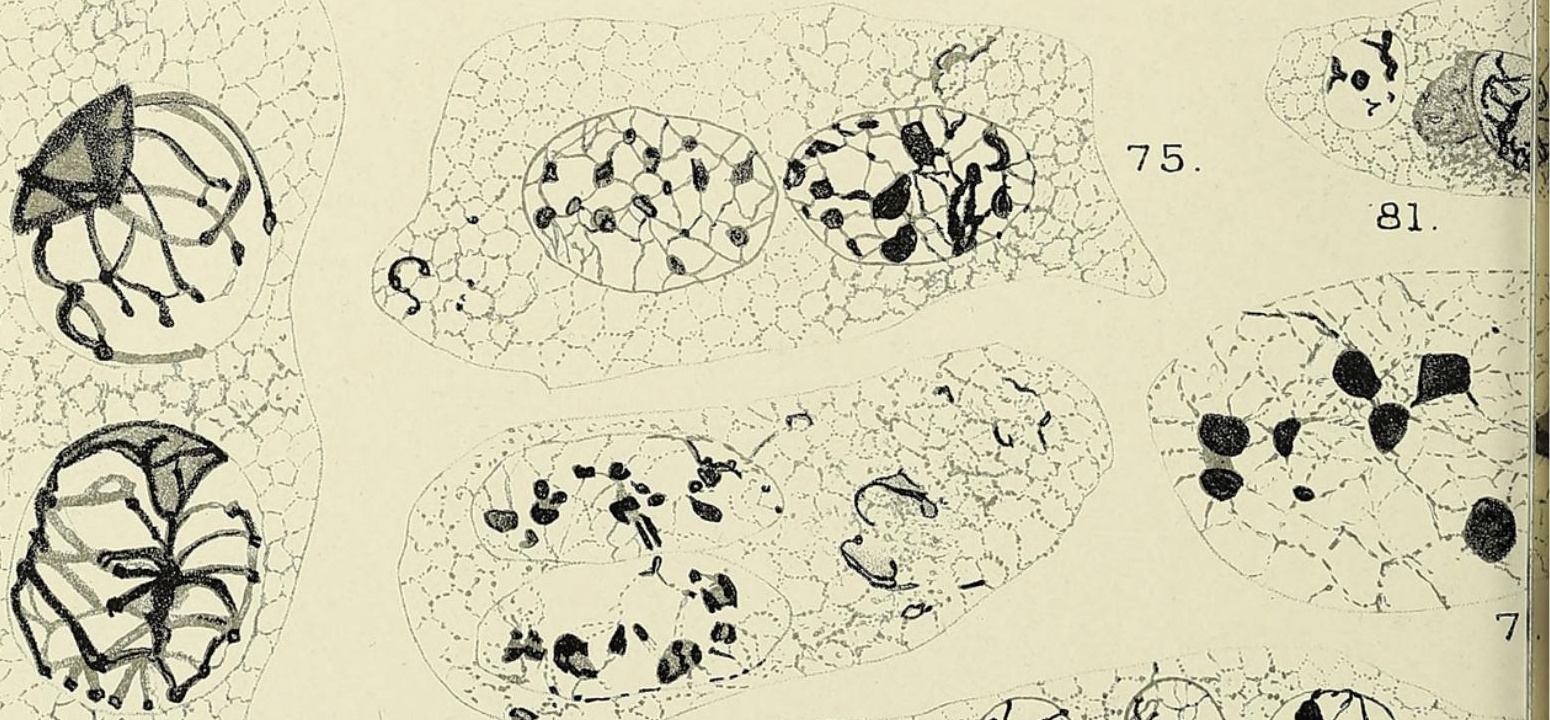

H. 76 .
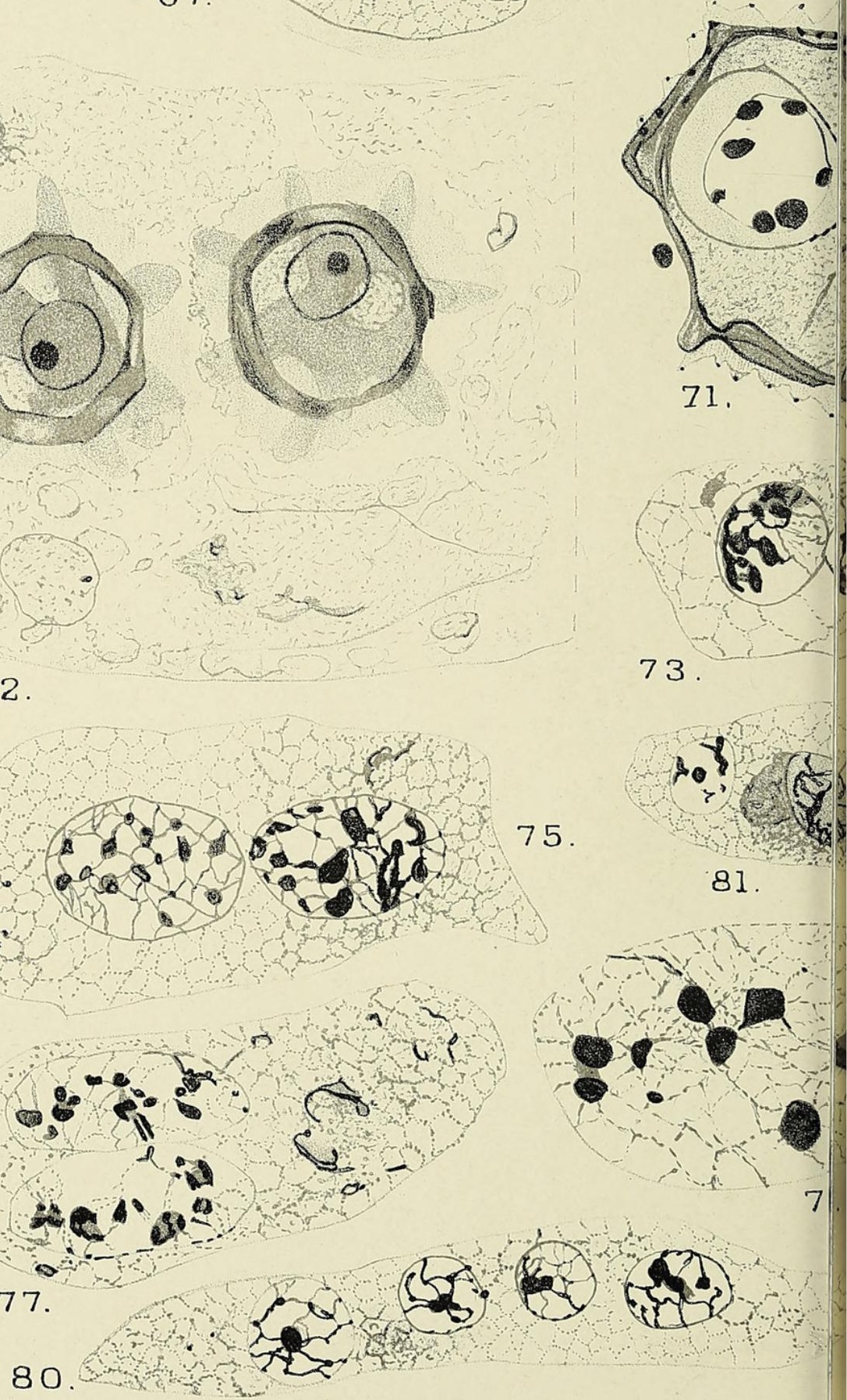

${ }^{3}=1$ 81
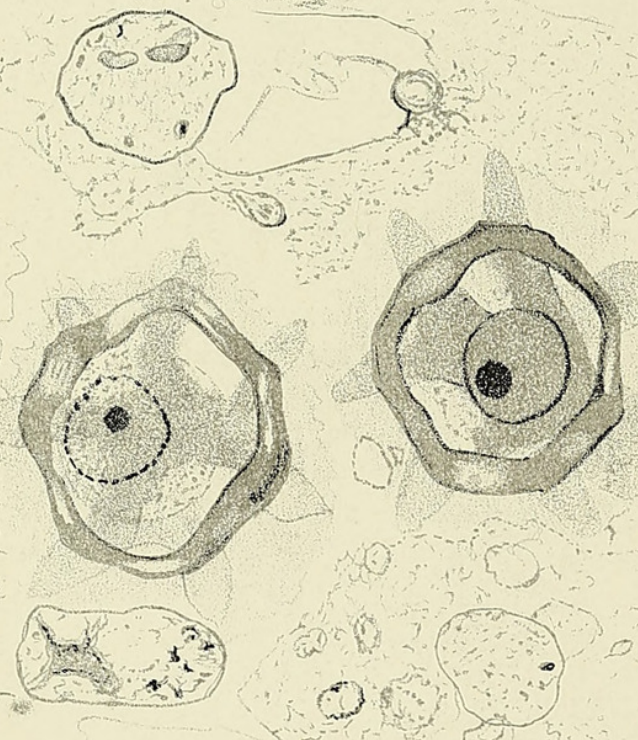

72. 
1208
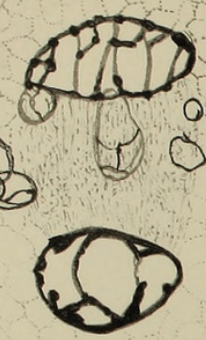

65

.

(x)

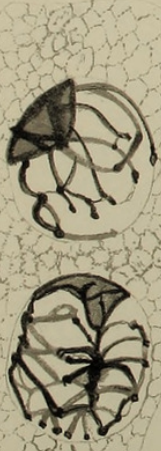

72

S. 50 a

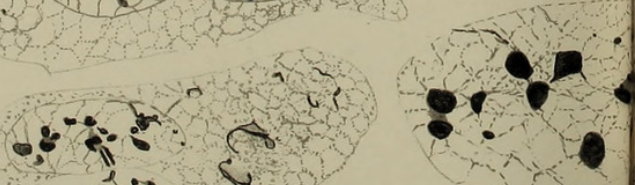

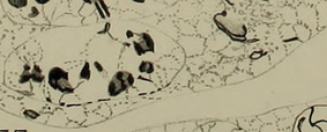

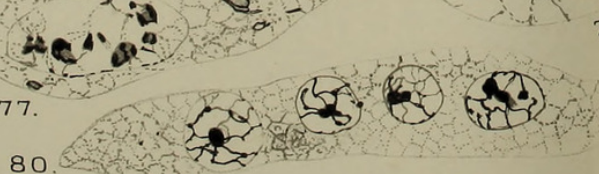
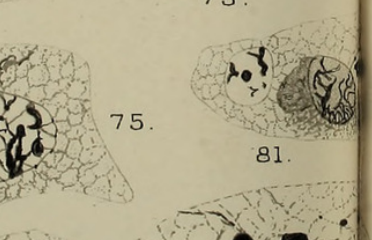

09

67

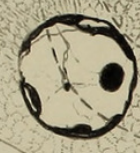

(3)

$2+4$

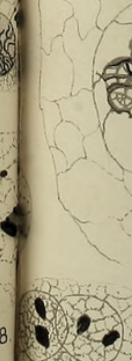

(2)

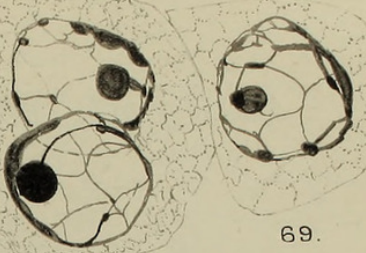

69

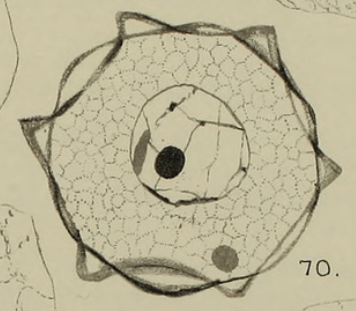

(i) 3

(स)

68.

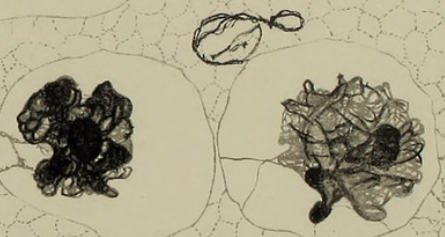

82.
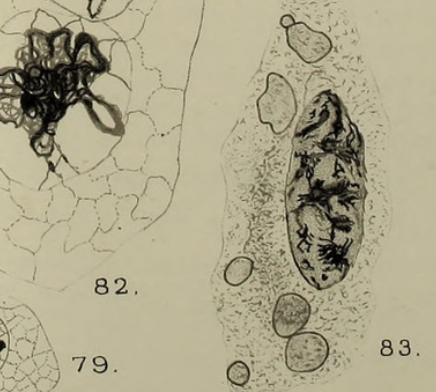

74.
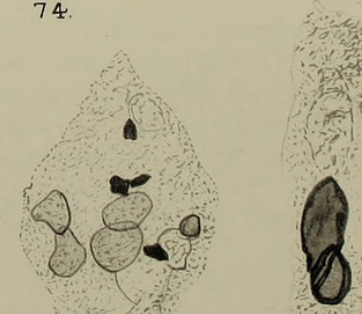

(20)

(2)

GATES AND REES - LACTUCA. 


\section{$2 \mathrm{BHL}$ Biodiversity Heritage Library}

Gates, R. Ruggles and Rees, E. M. 1921. "A cytological study of pollen development in Lactuca." Annals of botany 35, 365-398. https://doi.org/10.1093/oxfordjournals.aob.a089763.

View This Item Online: https://www.biodiversitylibrary.org/item/235780

DOI: https://doi.org/10.1093/oxfordjournals.aob.a089763

Permalink: https://www.biodiversitylibrary.org/partpdf/319008

\section{Holding Institution}

Smithsonian Libraries

\section{Sponsored by}

Biodiversity Heritage Library

\section{Copyright \& Reuse}

Copyright Status: Not in copyright. The BHL knows of no copyright restrictions on this item.

This document was created from content at the Biodiversity Heritage Library, the world's largest open access digital library for biodiversity literature and archives. Visit BHL at https://www.biodiversitylibrary.org. 